1134

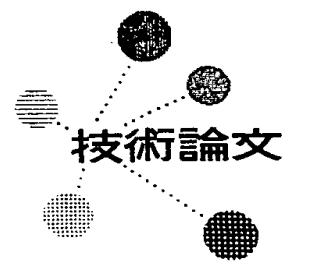

\title{
普通鋳鋼品 の疲れ強さ*
}

千々岩健児 ${ }^{* *}$, 大内田 久 ${ }^{* * *}$, 星野次郎 ${ }^{* * * *}$, 西岡邦夫*****

\section{1. 本研究の目的}

従来金属材料の疲れ強さに関しては多くの研究が行 なわれ，機械の設計ならびに使用上の有効な資料が与 えられているが，鋳鋼品について(1)はいまだ分では ない，特に大形鉡鋼品の疲れ強さや，鋳造品独特の欠 陥であるピンホール，ブロホール拉よびひけ巣を有す るものについての資料は皆無といってもさしつかえな W.

しかるに鋳鋼品は船用部品, 車両部品, 産業機械部 品など耐久性を要する場所に多く使用され，その疲れ に対する強さの資料は，これら設計上必要欠くへからら ざるものであって，斯界より強く要望されているもの である。

著者らはこの要望をみたすため鋳鋼品の試験片とし て普通の試験片の他に大形 $(50 \mathrm{~mm} \phi, 100 \mathrm{~mm} \phi)$ の ものを製作し，また実体（スタンフレーム）より試験 片を切出し，欠陷のないものと欠陷のあるものとの痩 れ強さを求め，また破壊時の破面の状態を詳細に観察 し, 試験片の大きさ, ブロホール,ひけ巣などの疲れ 強さに及ほす影響を明らかにすることを試みた。

\section{2. 実験項目と試験片の製作・検査}

本研究では鋂鋼品の回転曲げ，片振り弓張り，両振 り弓張珠縮の各痩れ強さを求めることとし, つぎの各 項の実馻を行なった（表 1 参照).

(1) 健全材 $(10 \phi, 50 \phi, 100 \phi)$ ならびに穴あけ試 験材 $(10 \phi, 50 \phi, 100 \phi)$ の回転曲げ痩れ試験.

(2): 久陷材 $(50 \phi, 100 \phi)$ の回転曲汗疲れ試験.

(3) 健全材 $(35 \phi)$ ならびに久陷材 (35 $\phi)$ の片振 り弓涱疲れ試験.

(4) 健全材 $(20 \phi)$ ならびに久俻材 $(35 \phi)$ の雨振 り弓㖘圧縮試験.

本研究の実施にあたっては，試験片の製作に特に留 意し、またその検查を笝重に行なった，特に任意の大

\footnotetext{
* 原稿受付 昭和 41 年 5 月 7 日.

** 正員, 東京大学工学部 (東京都文京区本郳 7-3-1).

*** 正員, 日立製作所日立研究所.

$* * * *$ 正員, 日本海事協会技術研究所.

***** 正員, 住友金属工業会社中央技術研究所.
}

きさと数の久陷を有する試験片を製作することははな はだしく困難であったが，特別な注意を払って製作し た多くの試験片を検查し，それより抽出分類すること によって目的を详成することができた，久䧄の程度の 分類には肉眼検查，放射線㭘查，磁粉探傷試験，染色 浸透試験を併用し，さらに実験の結果破面に現わ礼た 久樎により多少の補正を行なった。

\section{3. 健全材ならびに穴あけ試験片の回転曲げ 疲れ試験}

$3 \cdot 1$ 試験の目的 ブロホール欠陷の疲れ強さに及 はすす影響を調べるため，これらの代わりに丸穴を試験 片の軸に直角方向にあけて調べることにした。この橫 穴試験片を選んだのはつぎの理由による。

(1) 鋳造によって一定の位置に一定大きさのブロホ 一ルを作ることはできない。

(2) 健全材に横穴をあける試験片は製作が容易であ りそその大きさを変えることにより，ブロホール の大小との関連性をつけることができる.

(3)穴あけ試験片は開口したブロホールと考えるこ とができる．内部にあるブロホールにくらべて， 表面に現われたこれらの久陷のほうが回転曲げ疲 れ試験では強度的に条件がきびしく，影響度が大 きくあらわれるものと考えられる。

(4) 丸棒に横穴がある場合の疲れ強さは，各種の鍛 鋼についてかなりの実験が行なわれているので, この結果と比較することにより，鋳鋼の特異性の 判断ができる。

$3 \cdot 2$ 試験の方法 表 1 および図1に示すように $10 \mathrm{~mm} \phi, 50 \mathrm{~mm} \phi, 100 \mathrm{~mm} \phi$ の各試験片に各種寸法 の穴をあけ，穴径 $d$ のみの影響と穴径 $d$ と試験片直 径 $D$ との比 $d / D$ の影響艺求め得るようにした。穴の 深さhは大きい穴では貫通させ，小さいものでは $h>$ $5 d$ とし，舟側にあけた。

また穴の深さの影響を求めるため $50 \mathrm{~mm} \phi$ 試験片 では深さの異なるものの実験も行なった。試験機はつ ぎのとおりである.

$10 \mathrm{~mm} \phi$ 試験片：小野式回転曲げ疲れ試験機 $8 \mathrm{~kg} \mathrm{~m}, 2000 \mathrm{rpm}$ 
$50 \mathrm{~mm} \phi$ 試験片：片持回転曲げ度れ試験機

$400 \mathrm{~kg} \mathrm{~m}, 1200 \mathrm{rpm}$

$100 \mathrm{~mm} \phi$ 試験片：片持回転曲げ疲れ試験機

$7500 \mathrm{~kg} \mathrm{~m}, 1250 \mathrm{rpm}$

$3 \cdot 3$ 取りまとめの方法 穴を貫通させたものも， そうでないものも貫通した穴と考え，次式で応力のを 計算した。

$$
\begin{aligned}
& \sigma=\frac{M}{\pi D^{3}-\frac{d D^{2}}{6}} \quad \begin{array}{l}
M: \text { 曲げモーメント } \\
\text { 試験片直径 }
\end{array} \\
& 32-\frac{d}{6} d: \text { 穴の直分 }
\end{aligned}
$$

各試験片とも応力繰返し数 $10^{7}$ 回で破断しなかった 場合，その上限庆力を疲れ限度とした。

$10^{7}$ 回の応力繰返しに耐えて破断しなかったもので も，穴の縁に微細な疲れき裂を生じている場合もある ので，疲れ限度をつぎのごとく区別してあらわすこと にした。

$\sigma_{w 2}$ ：き裂の発生している場合の疲れ限度

$\sigma_{w 1}$ ：き裂の発生していない場合の疲れ限度

$\sigma_{w 0}$ : 穴を無視して求めた断面係数で $\sigma_{w 2}^{2}$ の值を修 正した值

また穴のない試験片の疲れ限度の值を，これらの疲
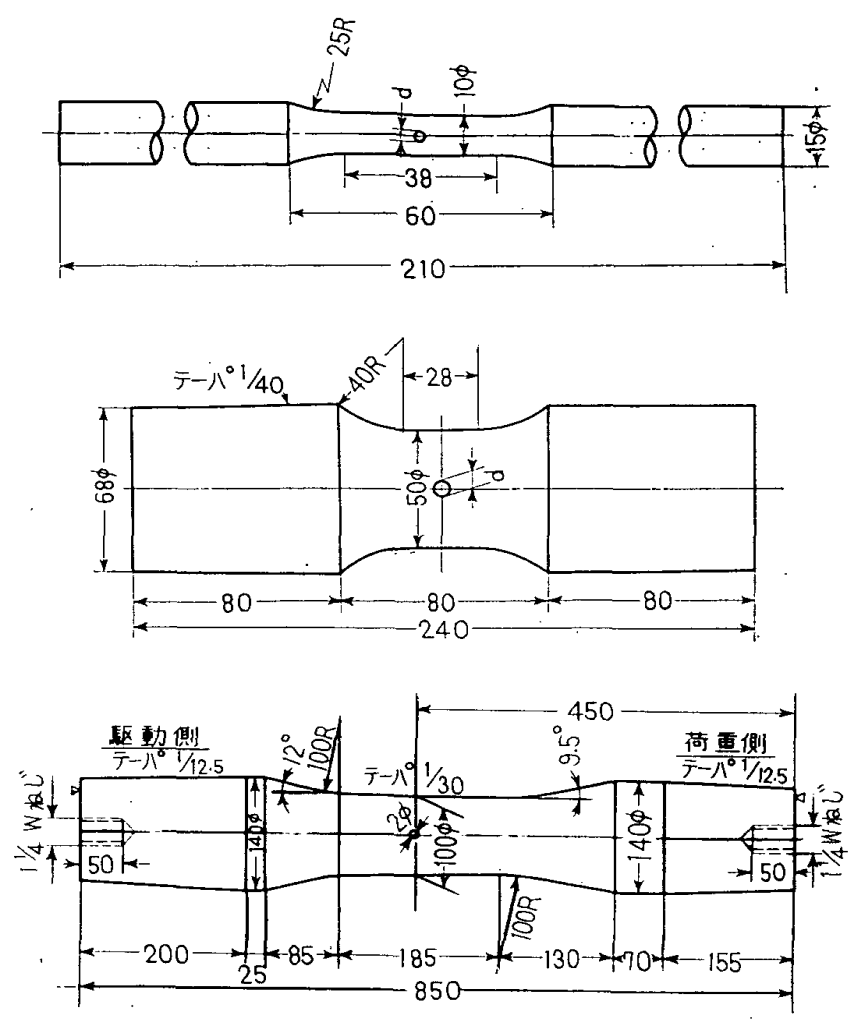

図 1 回転曲げ波れ試験片の形状・寸法

\begin{tabular}{|c|c|c|c|c|}
\hline 試験の種類 & 欠陥の種類 & $\begin{array}{c}\text { 試験片の直径 } \\
\mathrm{mm}\end{array}$ & 穴または欠陥の大きさ & 備 \\
\hline \multirow{8}{*}{$\begin{array}{l}\text { 回転曲げ } \\
\text { 波れ試験 }\end{array}$} & 健 全 & $10 \phi, 50 \phi, 100 \phi$ & $\begin{array}{l}100 \phi \text { では } 0.2 \mathrm{~mm} \text { 以下の ピンホールは } \\
\text { 健全材と考え得た. }\end{array}$ & 3〜10 個のピンホールがある のがあった. \\
\hline & \multirow{3}{*}{$\begin{array}{l}\text { きりで穴あけ } \\
\text { (人工的に加工) }\end{array}$} & $10 \phi$ & $\begin{array}{c}\frac{d}{D}=0.03,0.05,0.1,0.2 \\
(d=0.3,0.5,1.0,2.0 \mathrm{~mm})\end{array}$ & \multirow{3}{*}{$\begin{array}{l}d: \text { 穴の直径 } \\
D: \text { 試験片直堡 } \\
h: \text { 穴の深さ } \\
h>5 d \\
\text { ( ) } \text { ) }\end{array}$} \\
\hline & & $50 \phi$ & $\begin{array}{l}0.01,0.02,0.05,0.1 \\
(0.5,1.0,2.5,5.0 \mathrm{~mm})\end{array}$ & \\
\hline & & $100 \phi$ & $\begin{array}{l}0.02 \\
(0.2 \mathrm{~mm})\end{array}$ & \\
\hline & ブロホール & $100 \phi$ & $\begin{array}{l}0.5 \sim 1.5 \mathrm{~mm} \text { 小ブロホール } \\
4.0 \sim 8.0 \mathrm{~mm} \text { 大ブロホール }\end{array}$ & $\begin{array}{l}0.2 \mathrm{~mm} \text { 以下のちのもあわせて } 10 \sim 20 \text { 個 } \\
\text { 小ブロホールちあわせて } 10 \sim 30 \text { 個 }\end{array}$ \\
\hline & プロホール & $50 \phi$ & $\begin{array}{ll}0.4 \sim 1.0 \mathrm{~mm} & \text { 小ブロホール } \\
1.5 \sim 2.5 \mathrm{~mm} & \text { 中ブロホール } \\
3.0 \sim 5.0 \mathrm{~mm} & \text { 大ブロホール }\end{array}$ & $\begin{array}{l}\text { 5 17 個 } \\
\text { 小ブロホールもあわせて 8 19 個 } \\
\text { 小・中ブロホールもあわせて } 12 \sim 28 \text { 個 }\end{array}$ \\
\hline & ひけ栄 & $100 \phi$ & 5 10 mm 中心部のひけ巣 & \\
\hline & ひけ割れ & $64 \phi$ & $\begin{array}{l}0.5 \sim 7.0 \mathrm{~mm} \\
\text { 破罣の原因となったものは } 1.0 \sim 4.5 \mathrm{~mm}\end{array}$ & $\begin{array}{l}\text { 実体より切出し. } \\
\text { ひけ割れ } 1 \sim 6 \text { 個, 他にブロホールのあるちのもある. }\end{array}$ \\
\hline \multirow{3}{*}{$\begin{array}{l}\text { 振り引張 } \\
\text { 疲れ試 験 }\end{array}$} & 全 & $35 \phi$ & & \\
\hline & ブロホール & $35 \phi$ & $\begin{array}{l}0.2 \sim 1.0 \mathrm{~mm} \\
1.5 \sim 3.0 \mathrm{~mm}\end{array}$ & $\begin{array}{l}6 \sim 57 \text { 個 } \\
\text { 小ブロホールもあわせて 4 69 個 } \\
\text { 小・中ブロホールもあわせて } 23 \sim 68 \text { 個 }\end{array}$ \\
\hline & ひ け 巣 & $35 \phi$ & 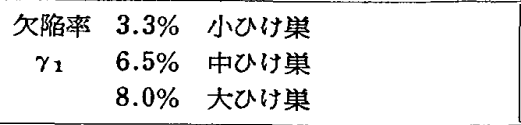 & \\
\hline \multirow{2}{*}{$\begin{array}{l}\text { 引張王縮 } \\
\text { 疲れ試験 }\end{array}$} & 全 & $20 \phi$ & & \\
\hline & ブロホール & $35 \phi$ & $\begin{array}{l}\sim 0.7 \mathrm{~mm} \quad \text { 小ブロホール } \\
\text { 欠楩率 } \gamma_{1}=1.0\end{array}$ & 16 18 個 \\
\hline
\end{tabular}

表 1 試 験 片 の 種 類

注 欠陌の個数は試験片の表面にあらわれたものの数である. 
れ限度で除した值，すなわち切欠き係数をてれそれ $\beta_{2}, \beta_{1}, \beta_{0}$ であらわした。

$3 \cdot 4 S-N$ 曲線 図 $2,3,4$ はおのおの $10 \phi$, $50 \phi, 100 \phi$ の $-N$ 曲線を示す．穴のある場合は試験 片の大小にかかわらす健全材に比へて疲れ強さは低下 し，また穴が大きいほど低下度合む大きいことがうか がわれる。

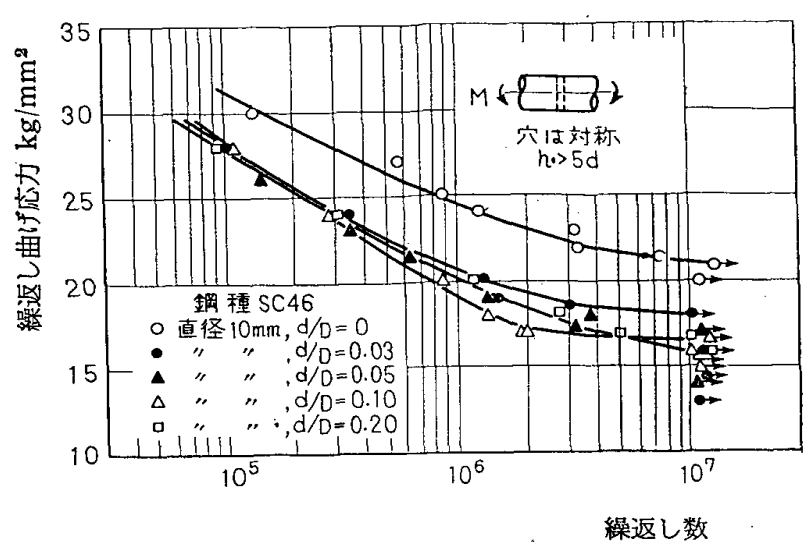

図 $210 \mathrm{~mm} \phi$ 回転曲げ試験片の $S-N$ 曲線

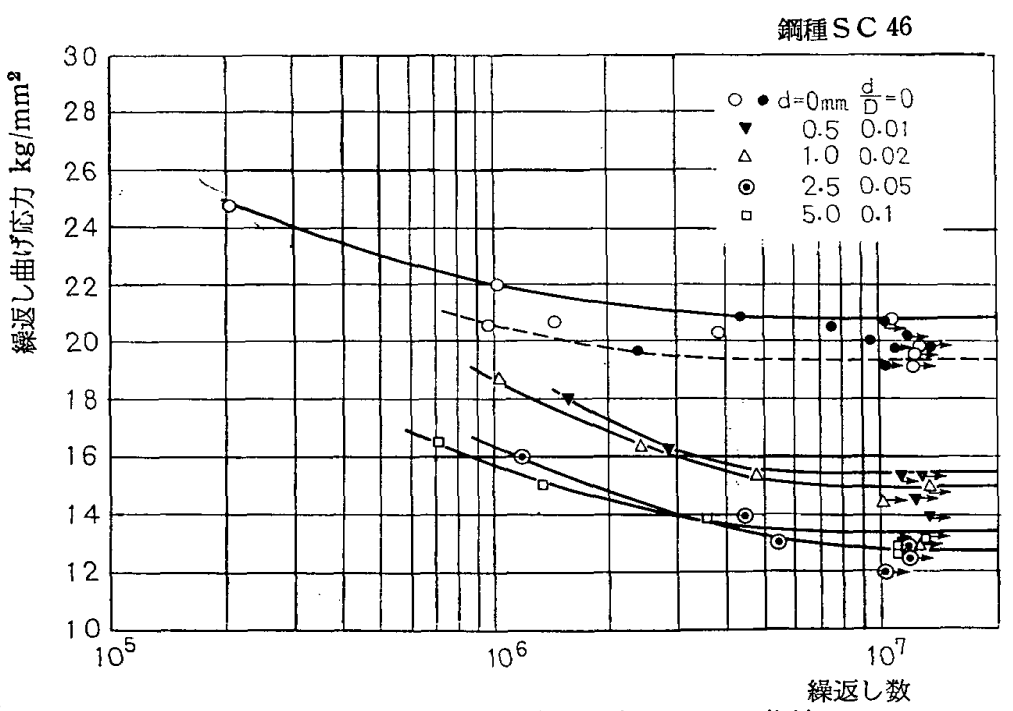

図 $350 \mathrm{~mm} \phi$ 回転曲げ試験片の $S-N$ 曲線

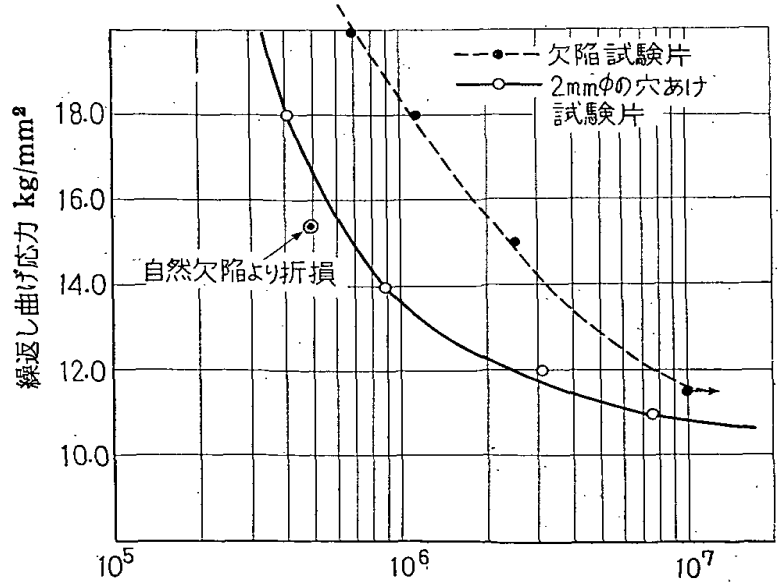

繰返し数

図 $4100 \mathrm{~mm} \phi$ 回転曲げ試験片の $S-N$ 曲線

Journal of the J.S.M.E., Vol. 69, No. 572
3 .5 破断状況 図 5 は穴あけ試験片の破断面状況 を示す。

この例は $50 \mathrm{~mm} \phi$ の場合であるが，他の場合もほ とんど同様な状況を呈している.

疲れ破壊は穴の表面付近，正確には若干内側の穴表 面から起こっている.

図 6 は $10^{7}$ 回以上で破断しなかった場合の穴の縁に

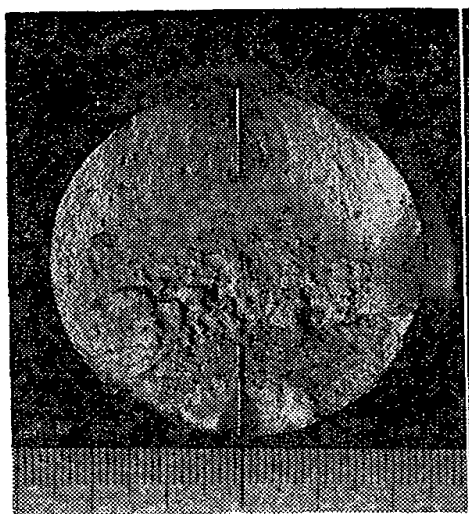

$1.0 \mathrm{~mm}$ 穴あけ試験片

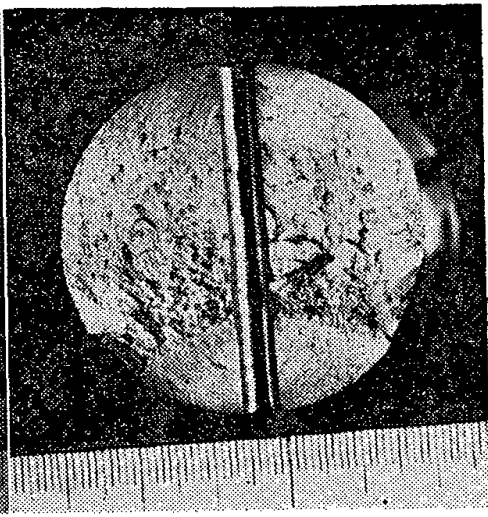

$5.0 \mathrm{~mm}$ 穴亦け試験片

図 $550 \mathrm{~mm} \phi$ 回転曲げ試験片の破断面

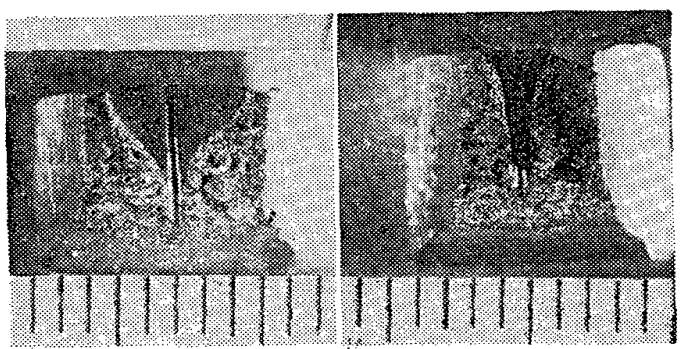

穴徍 $0.5 \mathrm{~mm}$

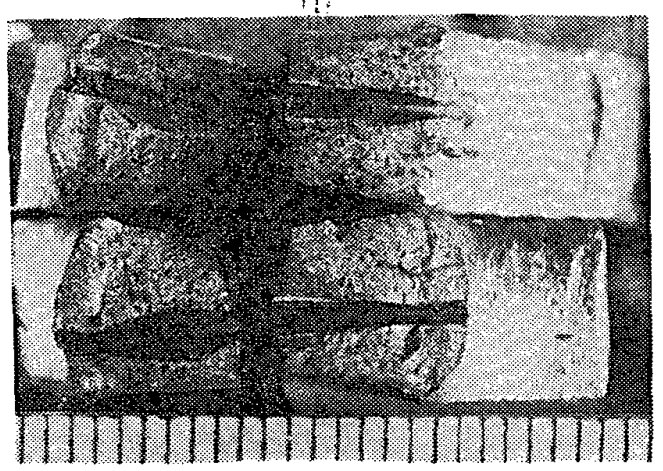

穴径 $1.0 \mathrm{~mm}$

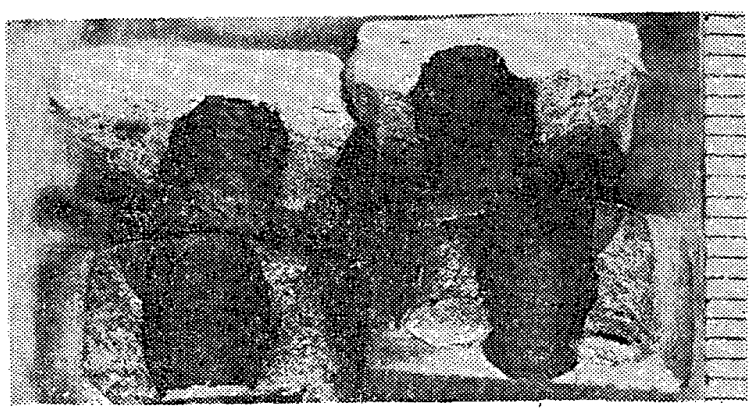

穴径 $5.0 \mathrm{~mm}$

図 $650 \mathrm{~mm} \phi$ 回転曲げ試験片の疲れき裂の状況

September, 1966 
き裂が発生していたものを後で静的に曲げて破断させ たものであり，黒ずんで見える部分は疲れ破面であ る.この状態で $10^{7}$ 回以上の繰返し数に耐えたもので ある。

3.6 疲九限度 $S-N$ 曲線吕ら疲れ限度を求め, 切欠き係数，引張強さに対する比などを一括して示す と表 2 のようになる。

$3 \cdot 7 D, d, d / D$ の影響 図 7,8 は試験片直径 $D$ が相異なる場合の $\sigma_{w 2}, \sigma_{w 1}, \sigma_{w 0}$ と $d / D, d$ との 関係を示す。

表 2 ならびにこれらの図からつぎのことがいえる.

(1) 穴のない場合の疲れ限度は，小さい試験片のほ うが大きく，大きい試験片のほうが小さい。直径 $10 \mathrm{~mm}$ 試験片の疲れ限度を 100 とすれば $50 \mathrm{~mm}$ 試験片では 98〜96, $100 \mathrm{~mm}$ 試験片では 88〜 79 である。

(2)疲れ限度は穴の大きさ，試験片の大きさの影響 をうける。

(3) 直径の異なる試験片の疲れ限度 $\sigma_{w 2}, \sigma_{w 1}, \sigma_{w 0}$ を $d / D$ が同じ場合について比較すると, 試験片が 小さい場合の疲れ限度のほうが大きい，たとえば $10 \mathrm{~mm}$ 試験片の度れ限度を 100 とすれば $50 \mathrm{~mm}$ 試験片のそれは約 80〜 75 であり，100 $\mathrm{mm}$ 試験 片では約 55 である.

(4) $d$ が同じ場合について比較すると， $\sigma_{w 2}, \sigma_{w 1} に$ は試験片の大きさの影響があるが， $\sigma_{u 0}$ は試験片 寸法に無関係にほほ同一の值を示す。

すなわち穴を無視した断面係数に基ついて求めた疲 れ限度は $d / D=0 \sim 0.2$ の範围において，穴の直径の みで定まると考えられる。これはつぎの理由によるも のと考えられる。すなわち穴を無視して求めた応力を 基準にして，穴の周囲に発生する最大応力に対して応
力集中係数 $\alpha$ を求めると四 9 のようになる：穴を考慮 した庆力に基ついた応力集中係数は同図に示すように $d / D$ が大になるほど一様に減少する(2)。これに反し， 今求めた $\alpha$ は $d / D=0 \sim 0.2$ の範国で $2.7 〜 3.0$ の間 にありほほほ等しい，したがって穴の付近の応力分布 は主として穴の直径 $d$ に影響されることになり， $d$ が 等しければ試験片寸法に無関係に同じ疲れ限度になる と思われる。

$3 \cdot 8$ 穴の深さの影響 これまでの実験では穴の深 さを直径の 5 倍以上にとって，穴の樑さの影響はない ものと考えたが，念のため穴の樑さの影響を求めた。

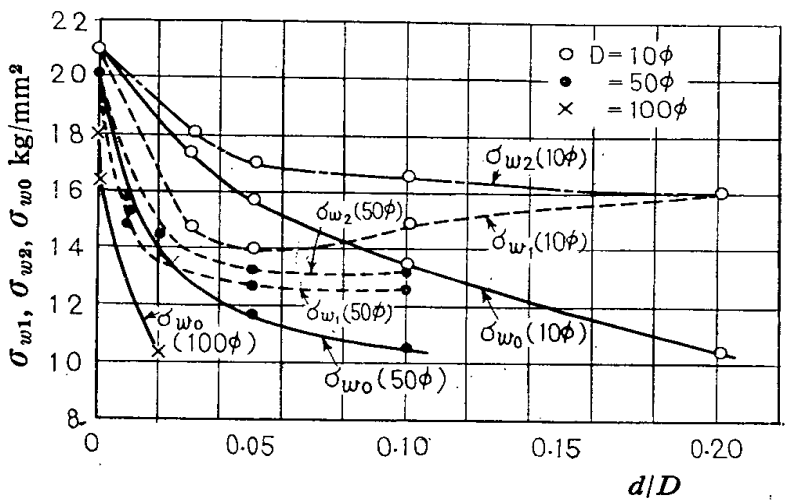

図 7 疲れ限度と $d / D$ との関係

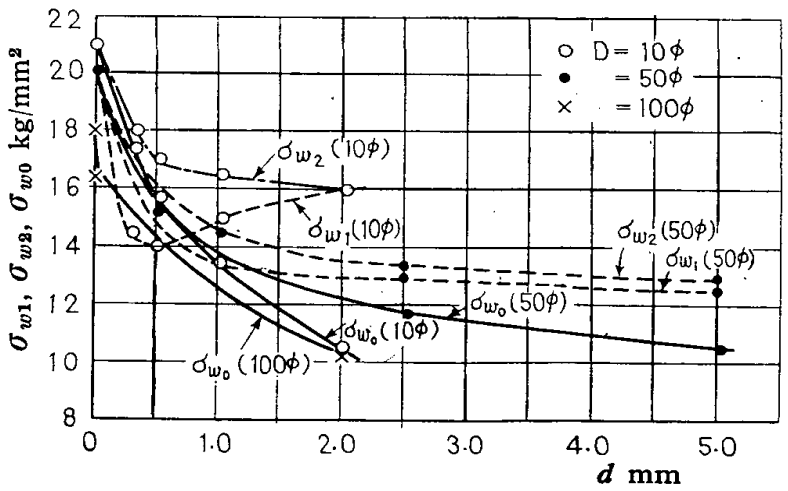

図 8 㾉れ限度と穴径との関係

表 2 穴あけ試験片の疲机限度

\begin{tabular}{|c|c|c|c|c|c|c|c|c|c|c|c|c|c|}
\hline \multirow{2}{*}{$\begin{array}{l}\text { 陚験片 } \\
\text { 惪 膲 } \\
D \mathrm{~mm}\end{array}$} & \multirow{2}{*}{$\begin{array}{l}\text { 穴 径 } \\
d \mathrm{~mm}\end{array}$} & \multirow{2}{*}{$d / D$} & \multirow{2}{*}{ 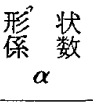 } & \multicolumn{3}{|c|}{ 疲九限度 $\mathrm{kg} / \mathrm{mm}^{2}$} & \multicolumn{3}{|c|}{ 切欠き係数 } & \multicolumn{3}{|c|}{ 引張強さに対する比 } & \multirow{2}{*}{ 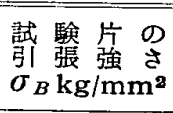 } \\
\hline & & & & $\sigma_{w \mathbf{0}}$ & $\sigma_{w 1}$ & $\sigma_{w \mathbf{2}}$ & $\beta_{0}$ & $\beta_{1}$ & $\beta_{2}$ & $\sigma_{w 0} / \sigma_{B}$ & $\sigma_{w \mathbf{1} / \sigma_{B}}$ & $\sigma_{w 2} / \sigma_{B}$ & \\
\hline \multirow{5}{*}{10} & 0 & 0 & 1.00 & $\begin{array}{l}21.0 \\
(20.5)\end{array}$ & - & - & 1.00 & - & - & $\begin{array}{c}0.46 \\
(0.44)\end{array}$ & - & - & \multirow{5}{*}{$\begin{array}{c}46.1 \\
47.0\end{array}$} \\
\hline & 0.3 & 0.03 & 2.59 & 17.4 & 14.5 & 18.0 & 1.21 & 1.16 & 1.45 & 0.38 & 0.32 & 0.39 & \\
\hline & 0.5 & 0.05 & 2.46 & 15.7 & 14.0 & 17.0 & 1.37 & 1.24 & 1.50 & 0.34 & 0.31 & 0.37 & \\
\hline & 1.0 & 0.10 & 2.26 & 13.5 & 15.0 & 16.5 & 1.55 & 1.27 & 1.40 & 0.29 & 0.33 & 0.36 & \\
\hline & 2.0 & 0.20 & 2.03 & 10.5 & 16.0 & 16.0 & 2.00 & 1.31 & 1.31 & 0.23 & 0.35 & 0.35 & \\
\hline \multirow{5}{*}{50} & 0 & 0 & 1.00 & $(20.1)$ & - & - & 1.00 & - & - & 0.38 & - & - & \multirow{2}{*}{$\begin{array}{c}52.5 \\
(48.7) \\
48.7\end{array}$} \\
\hline & 0.5 & 0.01 & 2.83 & 15.2 & 14.6 & 15.5 & 1.32 & 1.38 & 1.30 & $\begin{array}{c}(0.411) \\
0.31\end{array}$ & 0.30 & 0.32 & \\
\hline & 1.0 & 0.02 & 2,69 & 14.5 & 13.5 & 15.0 & 1.39 & 1.49 & 1.34 & 0.28 & 0.26 & 0.29 & 52.5 \\
\hline & 2.5 & 0.05 & 2.46 & 11.7 & 12.8 & 12.8 & 1.72 & 1.57 & 1.57 & 0.24 & 0.26 & 0.26 & 48.7 \\
\hline & 5.0 & 0.10 & 2.26 & 10.5 & 12.7 & 13.4 & 1.91 & 1.58 & 1.50 & 0.20 & 0.24 & 0.26 & 52.5 \\
\hline 100 & $\begin{array}{l}0 \\
2.0\end{array}$ & $\begin{array}{l}0 \\
0.02\end{array}$ & $\begin{array}{l}1.00 \\
2.69\end{array}$ & $\begin{array}{c}18.0 \\
(16.5) \\
10.5\end{array}$ & - & - & $\begin{array}{l}1.00 \\
1.71\end{array}$ & - & - & $\begin{array}{c}0.38 \\
(0.36) \\
0.21\end{array}$ & - & - & $\begin{array}{c}47.0 \\
(46.0) \\
48.8\end{array}$ \\
\hline
\end{tabular}


図 10 は穴の梁さ $t$ と底の丸み $\boldsymbol{r}$ を変えたものの $S-$ $N$ 曲線を示す。この図より $r$ と $t$ 等しい浅い穴で は，その大きさの影響 ( $3 \mathrm{~mm}$ と $6 \mathrm{~mm}$ の場合の差) はほとんど見られない $\left(\sigma_{w_{2}} / \sigma_{B}=0.3\right)$.それに比べ穴 が徍に比べて深い場合（半径 $3 \mathrm{~mm}$, 深さ $6 \mathrm{~mm}$ ) 动 は強さの低下がみられる $\left(\sigma_{w 2} / \sigma_{B}=0.25\right)$. しかしこ れ以上深くなった場合の強さの変化については前还の $50 \mathrm{~mm}$ 試験片の直隹の 5 倍の深さの穴において 2.5 $\mathrm{mm}$ 穴の場合 $\sigma_{w 2} / \sigma_{B}=0.26,5 \mathrm{~mm}$ 穴の場合 $\sigma_{w 2} / \sigma_{B}$ $=0.26$ となっていて, この場合の $\sigma_{w 2} / \sigma_{B}=0.25$ とほ とんど変わらない。したがって穴の深さが穴の直径の 1.5 倍以上になれば同じ疲れ強さになるものと考えら れる。

3.9 鍂鋼品と鍛鋼品との比較 この実験結果を鏙 鋼品の場合(3)(4)(5) と比較してみるとだいたいつぎのよ うなことが言える.

(1) 健全鋳鋼材（穴のないもの）の曲惊疲れ限度は 同じ弓張強さの鏾鋼材（SF 45 SF 50, 疲れ限度 $20 \sim 23 \mathrm{~kg} / \mathrm{mm}^{2}$ ) より低く，その約 $80 \%$ 程度で ある。

(2) 穴あけ鑆鋼材の切欠き係数は䤮鋼材よりも小さ い.また試験片寸法の相違による差も小さい.

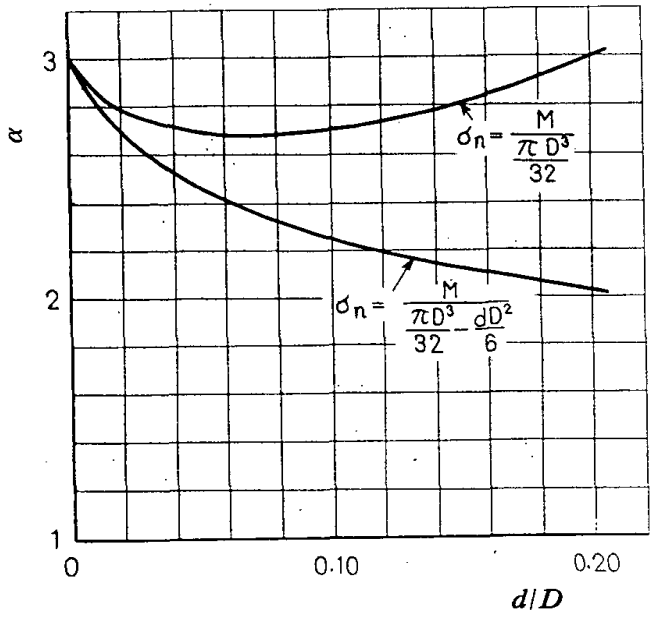

図 $9 d / D$ と応力集中係数 $\alpha$ との関係

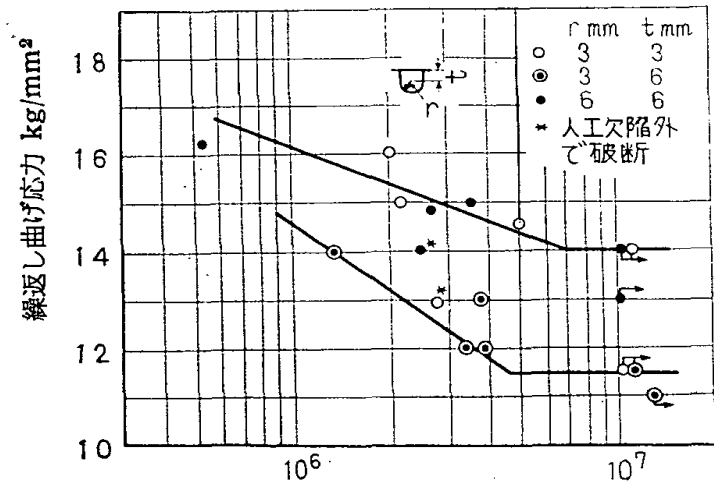

図 10 穴の深さの影響

\section{4. . 欠陥材の回転曲げ疲れ試験}

$4 \cdot 1$ 試験の目的 ブロホール，ひけ巣などの久陷 を有する大形鋳鋼品の回転曲壮疲れ强さを求め, その 影響を明らかにすることを目的とした。試験片として は $100 \mathrm{~mm} \phi, 50 \mathrm{~mm} \phi$ を使用した。

本試験では無欠扸の $100 \mathrm{~mm}$ 大形試験片の一端から $10 \mathrm{~mm}$ 試験片を採取し，その疲れ強さをも求めた。

4.2 欠陥の分類 肉眼検查, 放射線検查その他の 検查により欠宿を検出し，その結果 $100 \mathrm{~mm}$ 試験片で は $0.2 \mathrm{~mm}$ 以下（3〜10 個）のビンホールのあるもの， 0.5 1.5 mm（0.2 mm 以下のもあわせて 10〜20 個） のブロホールのあるもの，4〜8 mm（小ブロホールも あわせて 10〜30 個）のブロホールのあるものに区別 した. $50 \mathrm{~mm}$ 試験片では $0.4 \sim 1.0 \mathrm{~mm}$ (5〜17 個)の 小ブロホール，1.5〜2.5 mm（小ブロホールもあわせ て 8 19 個) の中ブロホール, 3.0 $5.0 \mathrm{~mm}$ (小.中 ブロホールをあわせて 12〜28 個）の大ブロホールに 区別した。

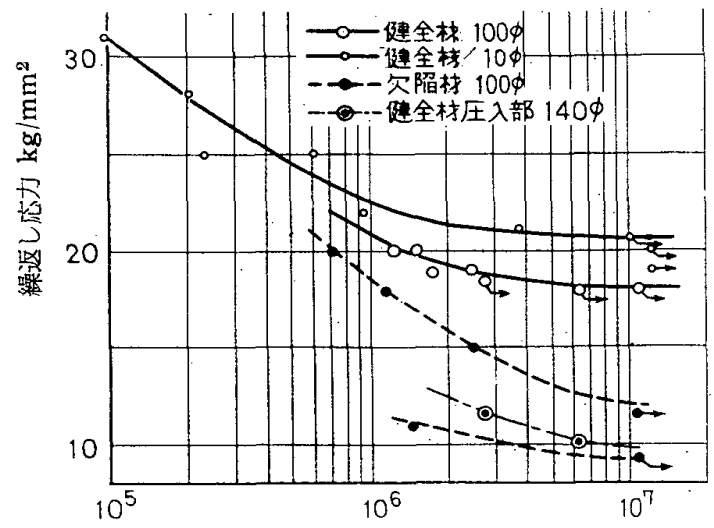

繰返し数

図 $11100 \mathrm{~mm} \phi$ 回転曲げ武験片（欠陥材）の $S-N$ 曲線

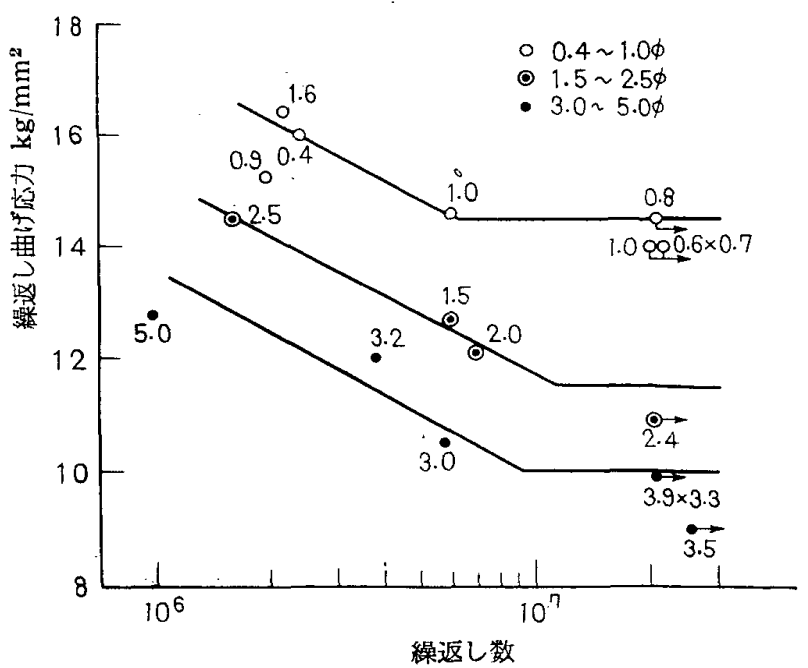

図 $1250 \mathrm{~mm} \phi$ 回転曲げ武験片（欠陥材）の $S-N$ 曲線 
なお試験結果破断面の検查により欠砏の量を確認 し，修正を行なった。

$4 \cdot 3 S-N$ 曲線 図 11 は直径 $100 \mathrm{~mm}$ およびそ の一端からとった $10 \mathrm{~mm}$ 試験片の疲れ試験結果を, 図 12 は直隻 $50 \mathrm{~mm}$ 試験片の結果を $S-N$ 線図として 示したものである.同図には，き裂が発生せずつかみ 部で破断したものについては, 試験部はつかみ部で破 断した繰返し数まで試験し異常を生じなかったデータ として，またつかみ部ではき裂発生部 の応力振幅と繰返し数を，それぞれプ ロットした。

なお大きな欠陷のあるものについて は，久陷加らその直圣の的 2 倍だけ円 周方向に離れた位置に取付けた抵抗線 ひずみゲージの指示値によって応力を 表わした。

4.4 破断状況 $0.2 \mathrm{~mm}$ 以下のビ ンホールのあるものではこれらの表面 欠俩加らは痩れき裂は発生せず健全材 と同じであった。図 13 は $100 \mathrm{~mm}$ 健 全材, 図 14 は $50 \mathrm{~mm}$ 健全材の破面全 体抢よびき裂起点付近を示 す。袈起点には久樎は見 出されないが，破面の中央 部にはあばたが数多く現わ れている.これは鋳鋼品内 の微細なポロシティが原因 と想像される。

$0.5 \mathrm{~mm}$ 以上の表面欠陌 があると疲れき裂はここを 起点として発生した.因 15 はこの状沇を示す。これ以 上の大きなブロホールが表 面付近にある場合はもちろ ん疲れき裂の起点となる。
下はブロホール直徍の対数值に比例している。

4.6 表面欠陥の影響 径 $0.2 \mathrm{~mm}$ 以下のビンホ 一ルは瘦れき裂の起点となることはなくこの程度の 久陷を有する鋳鋼材は健全材とみなし得る。

径 $0.5 \mathrm{~mm}$ 以上のブロホールは疲れき裂の起点とな り，疲れ限度は表 3 のように低下する。

径 $3 \mathrm{~mm}$ 以上のブロホールで，表面から澡部に及ん でいる場合は疲れ限度はさらに低下する。
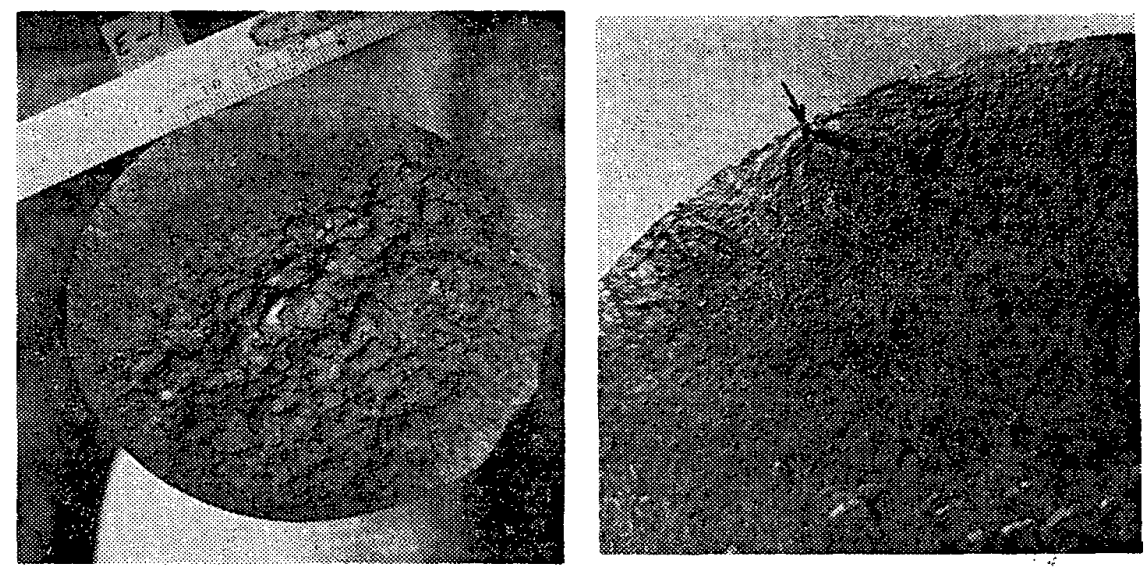

図 $13100 \mathrm{~mm} \phi$ 健全材の回転曲げ疲れ破断面（失印先端はき裂起点）
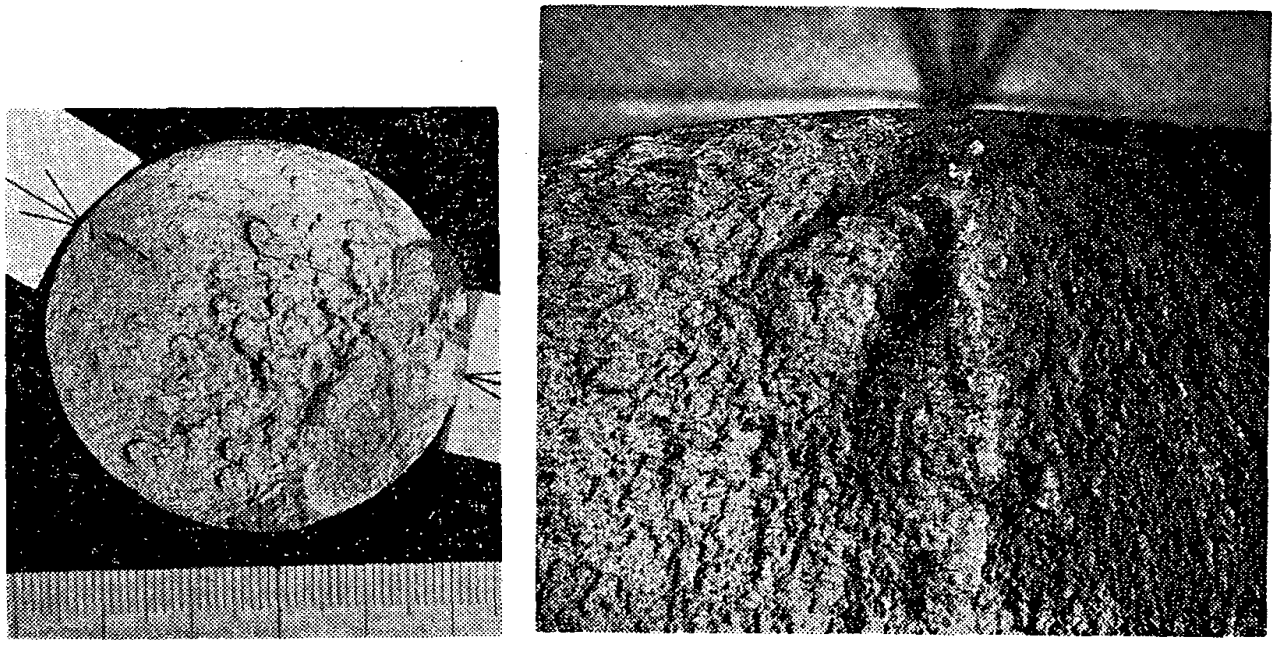

図 $1450 \mathrm{~mm} \phi$ 健全材の回転曲げ疲れ破断面（矢目先端はき裂起点）

\section{5 疲扎限度}

$S-N$ 曲線より， 回転曲げ痩れ限 度, 引張強さとの 比などを求めると 表 3 のようにな る.またブロホー ルの大゙きさと疲れ 限度との関係は図 16 (a) のようにな り，疲れ限度の低
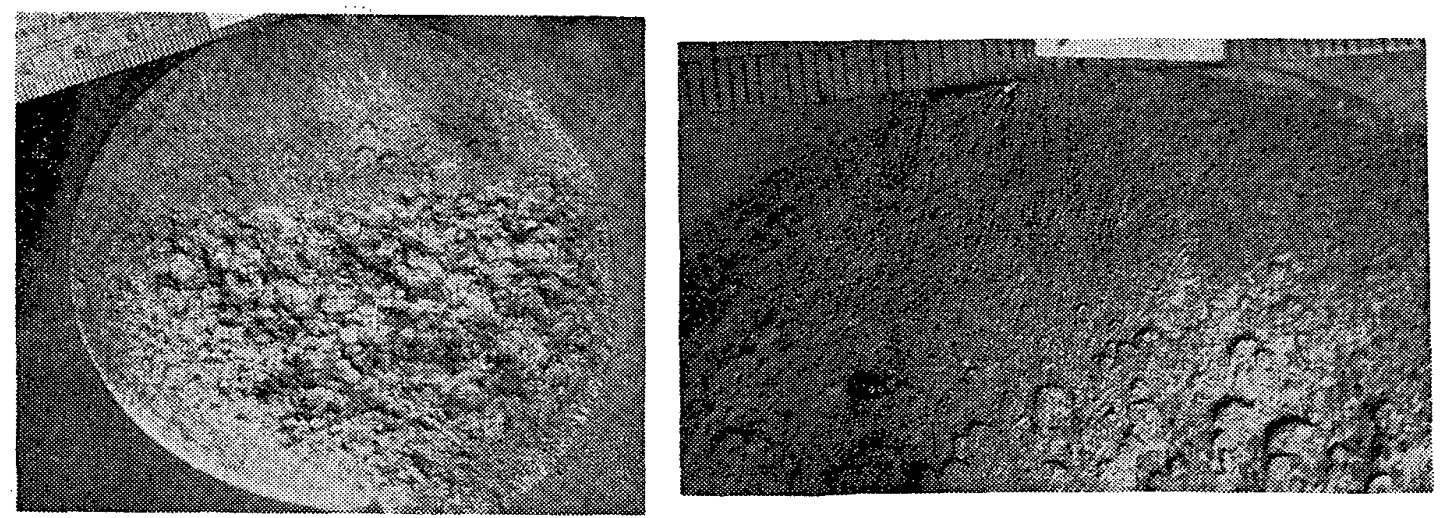

図 $151.0 \mathrm{~mm}$ のブロホールが起点となったちの (100 mm $\phi$ 試験片) 
4-7ひけ巣の影響 ひ巣については系統的な実 験を行なわなかったので正確なことはいえないが，試 験片中ひけ巣のあったものについて考えてみると軸心 部の試験片·直隹の 1/10 以下のひけではその影響は全 くないということがいえる。

これは今回行なった試験が試験片の軸心部にひけが ある場合のみであることによるためであろう. 表面に ひけ巣がくるような加工を行なえばその影響はあらわ れるものと思われる。

$4 \cdot 8$ 穴あけ試験片と欠陥試験片との比較 3,4 章 の両実験において, $100 \mathrm{~mm} \phi, 50 \mathrm{~mm} \phi$ 両試験片穴あ

表 3 久陷試験片の回転曲げ疲れ限度

\begin{tabular}{|c|c|c|c|c|c|}
\hline $\begin{array}{l}\text { 試験片 } \\
\text { 点徍 } \\
\text { mm }\end{array}$ & $\begin{array}{l}\text { ブロホー } \\
\text { ルの大き } \\
\text { さ } \mathrm{mm}\end{array}$ & $\begin{array}{c}\text { 引張強さ } \\
\mathrm{kg} / \mathrm{mm}^{2} \\
\sigma_{B^{*}}\end{array}$ & $\begin{array}{c}\text { 疲九限度 } \\
\mathrm{kg} / \mathrm{mm}^{2} \\
\sigma_{w 0}\end{array}$ & $\begin{array}{c}\text { 偯強され } \\
\text { 対す皆 } \\
\sigma_{w 0} / \sigma_{B}\end{array}$ & 考 \\
\hline \multirow{5}{*}{100} & & 46.0 & 16.5 & 0.36 & \\
\hline & $0 \sim 0.2$ & 48.5 & 18.0 & 0.37 & \\
\hline & & 47.0 & 18.0 & 0.38 & \\
\hline & $0.5 \sim 1.5$ & 53.9 & 12.0 & 0.22 & \\
\hline & $4 \sim 8$ & 53.9 & 9.2 & 0.17 & \\
\hline \multirow{4}{*}{50} & 0 & 52.5 & 20.1 & 0.38 & \\
\hline & $0.4 \sim 1.0$ & 47.7 & 14.5 & 0.31 & \\
\hline & $1.5 \sim 2.5$ & " & 11.5 & 0.24 & \\
\hline & $3.0 \sim 5.0$ & $n$ & 10.0 & 0.21 & \\
\hline 10 & 0 & 47.0 & 20.5 & 0.44 & $\begin{array}{l}100 \phi \text { 試験片 } \\
\left(\begin{array}{c}\sigma_{B}=47.0 \\
\mathrm{~kg} / \mathrm{mm}^{2}\end{array}\right) \\
\text { \&切出した } \\
\text { 亏. }\end{array}$ \\
\hline 64 & 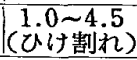 & 46.3 & 9.0 & 0.19 & 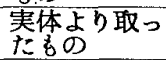 \\
\hline
\end{tabular}

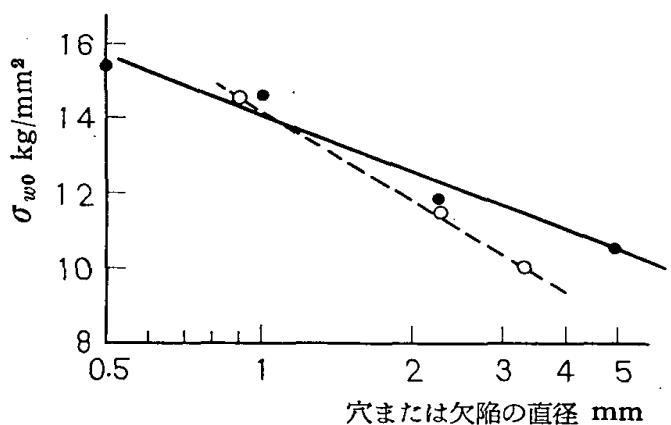

(a)

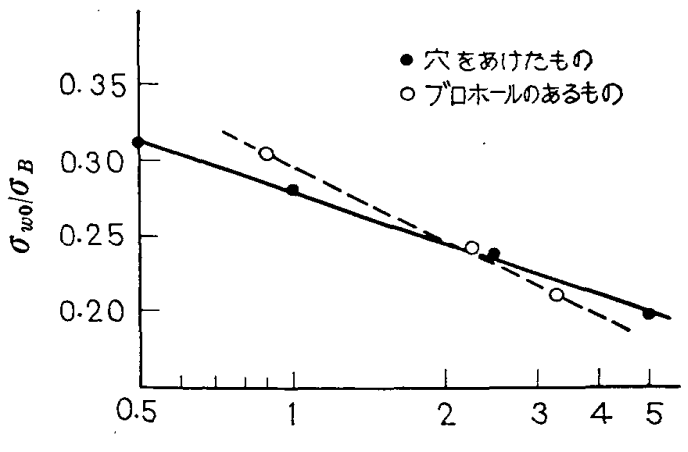

穴または欠陥の直径 $\mathrm{mm}$ (b)

図 16 穴あけ試験片とブロホール試験片と による疲れ強さの比較
けの場合とブロホール欠陷のある場合の両者を取扱っ たのでここの両者が同一径の場合について比較した.

因 16 に50 mm $\phi$ 試験の曲将疲れ限度 $\sigma_{w 0}$ とブロホー ル直径との関係を示した， $100 \mathrm{~mm} \phi$ 場合は穴あけ が $2 \mathrm{~mm} \phi$ のであるので比較できないが, $50 \mathrm{~mm} \phi$ の場合では穴またはブロホールの大きさによる疲れ限 度の低下はほほ等しいように思われる。ただ穴径によ って多少の差はでている.

この理由はブロホールのまわりはなめらかでなく多 少のぎさきさがあることと，ブロホールは 1 個でなく 破断面に数個ある場合があるための影響によるものと 考えられる.

したがって機械加工による穴によって，ブロホール やピンホール欠宿の場合を推祭する際には，穴があま り大きくない範囲では，両者はほほ $1: 1$ と考えてさ しつかえないものと思われる。

\section{5. 実体より切出した試験片の回転曲げ疲れ 試験}

$5 \cdot 1$ 試験の方法 図17に示すスタンフレムより 試験片を切りだし試験に供した。試験片は $64 \mathrm{~mm} \phi$ とし, 容量 $7800 \mathrm{~kg} \mathrm{~m}$ 回転曲げ疲れ試験機により試 験した。回転数は $800 \mathrm{rpm}$ とした。

$\mathbf{5} \cdot \mathbf{2}$ 試験片の欠陥の状態 実体より切出した試験 片であるため，ブロホールだけでなくひけ割れを伴う さく状欠陷が同時に存在して表面にあらわれた。しか もこれらの大きさも数もまちまちであったが，ブロ ホールの大きさは $0.5 \sim 2.0 \mathrm{~mm} \phi$, ひけ割れの大きさ は 0.5〜7.0 mm であった. しかしこれらのうち実際 に破壊の原因となったものは場所・方向などの関係か らひけ割れの $1.0 〜 4.5 \mathrm{~mm}$ であった。

$5 \cdot 3 S-N$ 曲線 欠陷の形状寸法はそろわなかっ たが,これらのものについて $S-N$ 曲線を描くと図 18 のように求まった。四中の数字は久陥の円周方向の長 さを示す。

この結果より $1.0 \sim 4.5 \mathrm{~mm}$ け割れを伴ったさく状 欠䧄を有する鋳鋼品の疲れ限度は $10^{7}$ 回で $9 \mathrm{~kg} / \mathrm{mm}^{2}$ とみられる。

$5 \cdot 4$ 破断状況 図19は破断面の代表例を示した ものである．表面值下の久陷から破壊が開始している ようすがわかる，微小欠陷を多く内蔵しているため前 还の例のようにあばたが多い。

5.5 製造試験片と実体試験片との相違 ブロホー ルのみの試験片に比へて実体より切出したこの試験片 ではちょうど表面または表面近くにひけ割れがでて いたため，痩れ強さが低いと考えられる（表 3 参照）。 


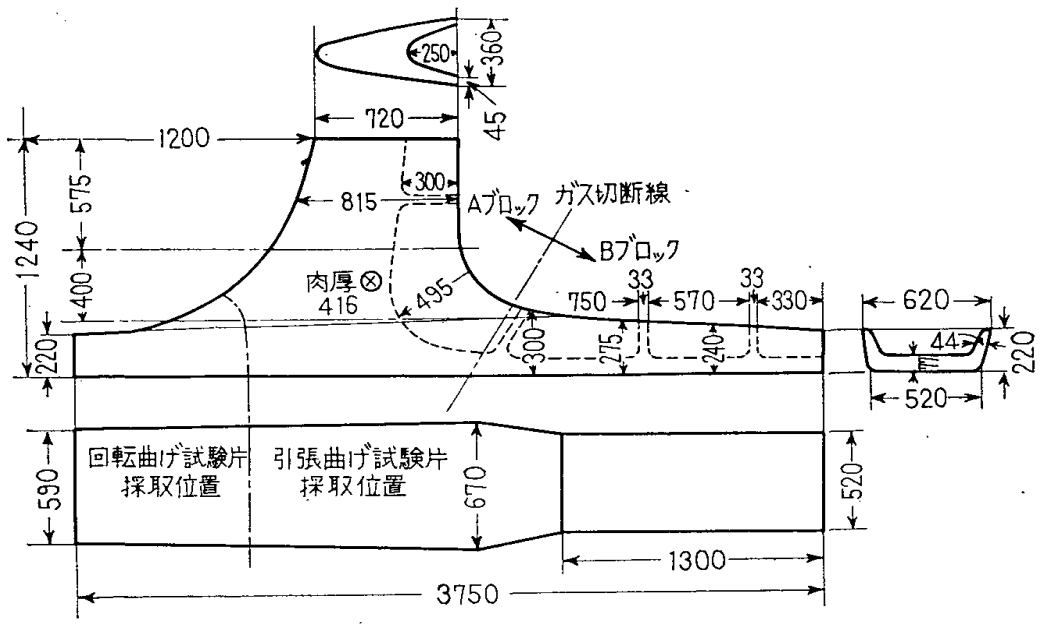

図 17 実体試験用スタンフレム

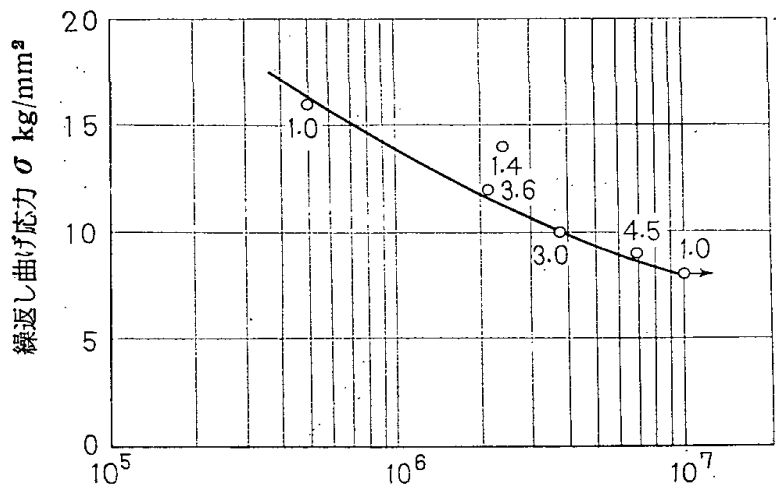

繰返し数

図 18 実体より切出した $64 \mathrm{~mm} \phi$ 回転曲げ 試験片の $S-N$ 曲線（数字は久陥の 円周方向の長さを表わす）

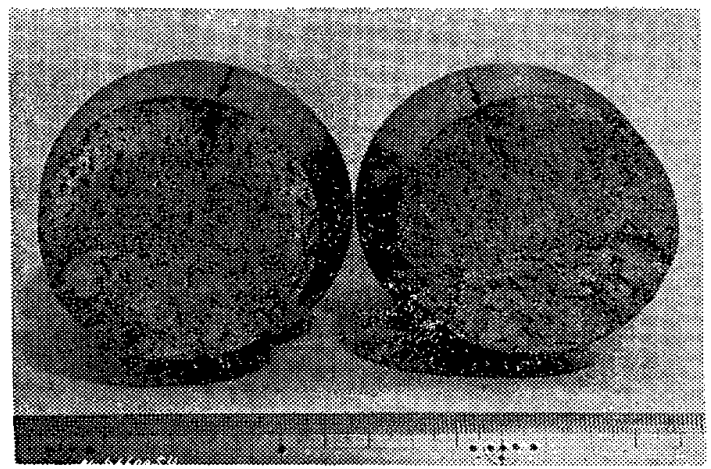

(a)

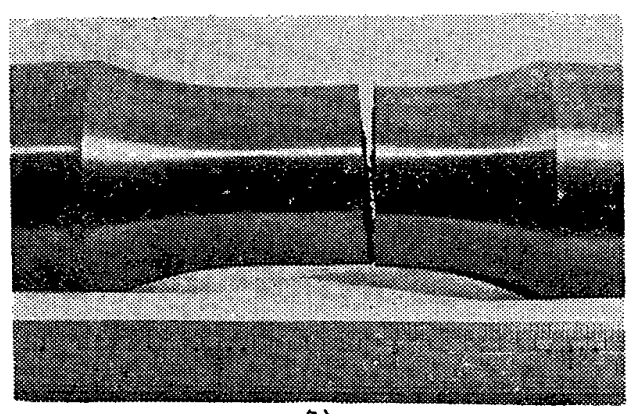

(b)

図 19 実体より切出した $64 \mathrm{~mm} \phi$ 回転曲げ 疲れ試験片の破断面

\section{6. 片振り引張疲れ試験}

$6 \cdot 1$ 試験の方法 四20は使用した 疲孔試験片 $(35 \phi)$ の形状・法を示す。 試験片は直径で $3 \mathrm{~mm}$ の仕上しろを残し た素材より旋削仕上げを行ない，平行部 は $0.4 \#$ の紙やすりで研摩したものを使 用した。

これらの試験片を欠陷の有無, 大小, 種類により表 4 のごとく 7 種類に分け た.

試験機はアムスラー形万能疲れ試験機 （容量 $50 \mathrm{t}$, 繰返し速度 $300 \sim 400 \mathrm{c} / \mathrm{min}$ ) を用いた。試験条件は下限汒力 $2 \mathrm{~kg} / \mathrm{mm}^{2}$ とし, 上 限応力を種々に変え, 応力繰返し数 $2 \times 10^{6}$ の疲れ強 さを求めた。応力は欠陷のための試験片断面の減少を 考虑しないで算出した。

6.2 $S-N$ 曲線 図 21, 22 は無久陥ならびにブ ロホール，ひけ巣を有する試験片の $S-N$ 曲線を示し たもので，たて軸は応力全振幅，横軸は応力繰返し数 である。

6 -3 破断状況 図 23 は代表的な大・中・小ブロ ホール試験片の破断状況を示したものである。

大・中ブロホール試験片の破断したものは，いずれ も表面にあったブロホールの最大のものから破罗が始 まっている.

小ブロホールでは中心部の大きな欠陷から破壊して いる例もあったが，だいたいは表面の小ブロホールが 起点となっていた.

図 24 は大・中・小ひけ巣試験片の破断面を示した

表 4 片振り引張疲れ試験片の分類

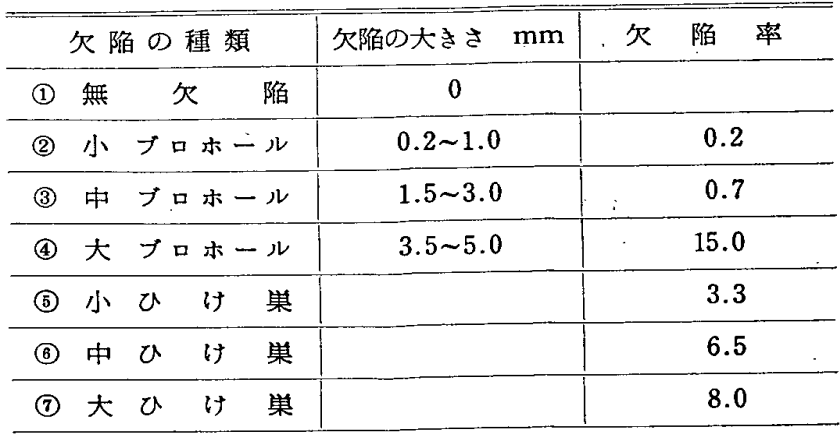

久陥率：疲れ破面にみられた久陥部面積と全断面積との比.

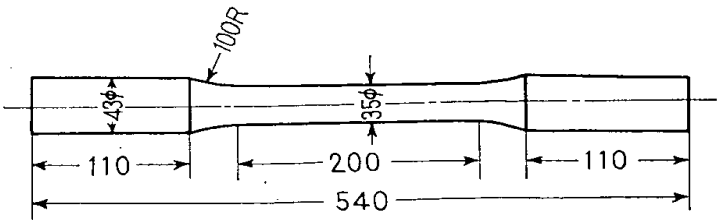

図 $2035 \mathrm{~mm} \phi$ 片振り引張疲れ試験片

昭和 41 年 9 是 


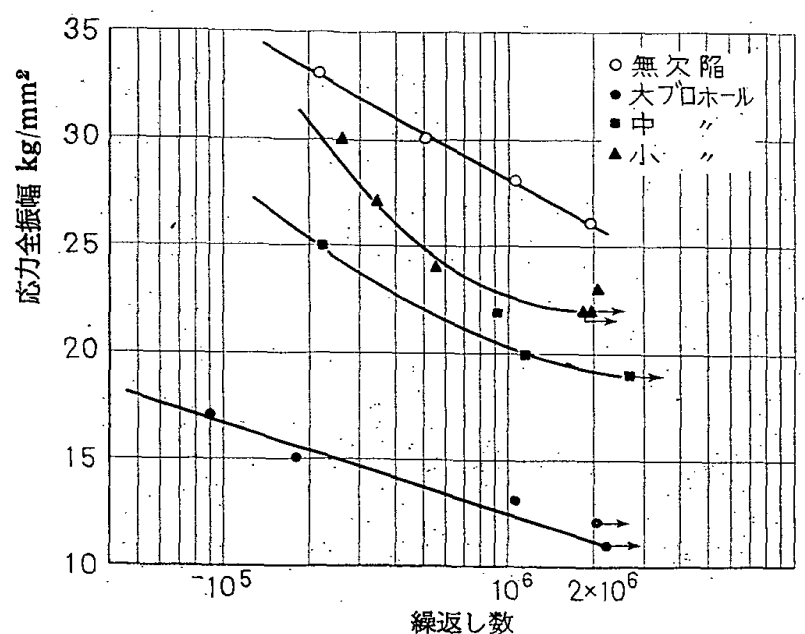

図 21 ブロホール欠陷試験片の片振り引張り $S-N$ 曲線
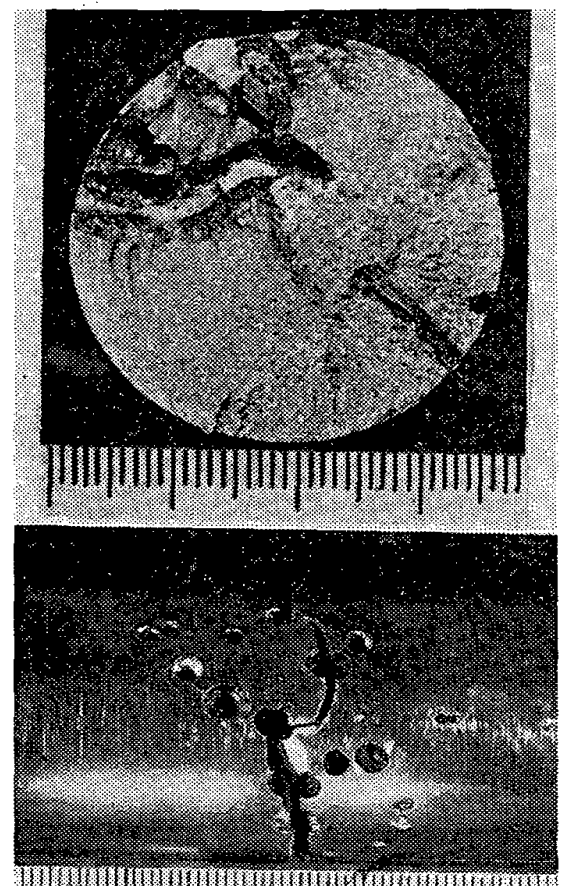

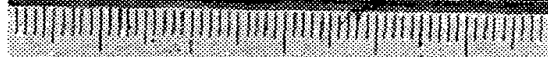

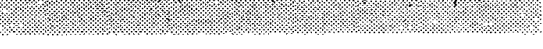

大プロホール

図 23 ブロホールを有する片振り引張疲れ試験片の破断状況

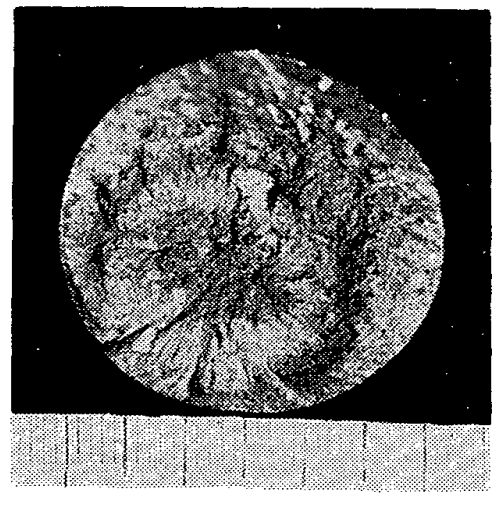

大ひけ
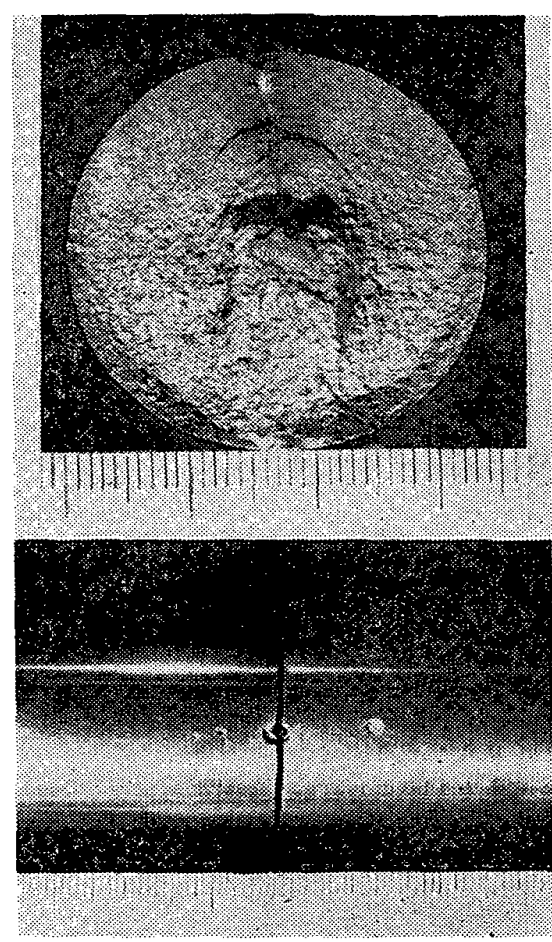

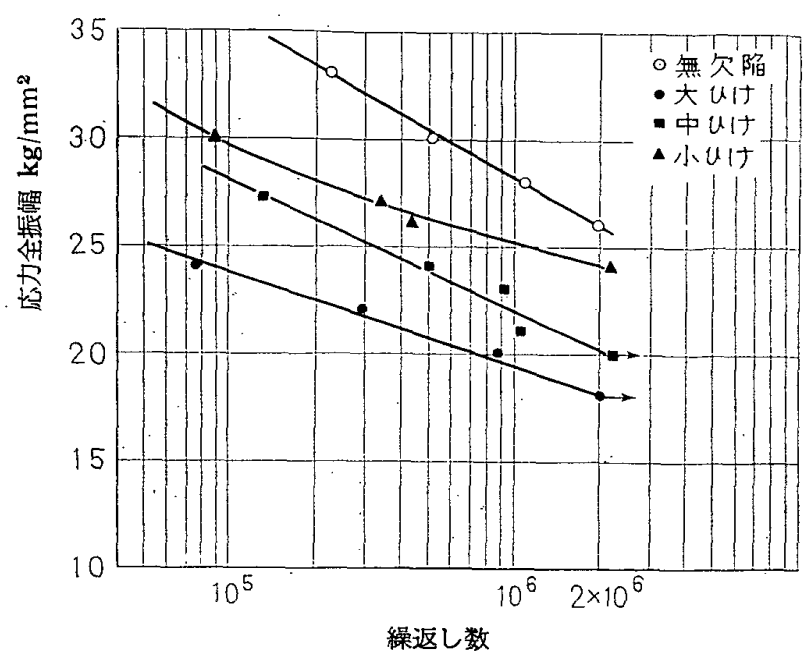

図 22 ひけ久陌試験片の片振り引張り $S-N$ 曲線
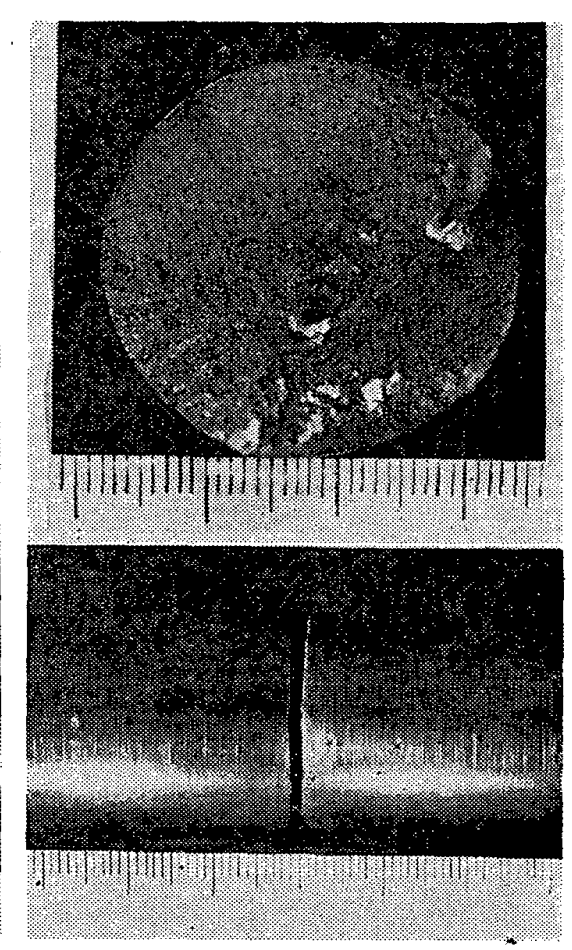

小ブロホール

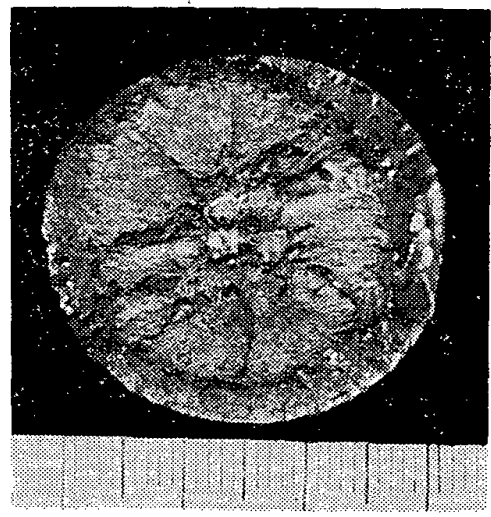

中ひけ

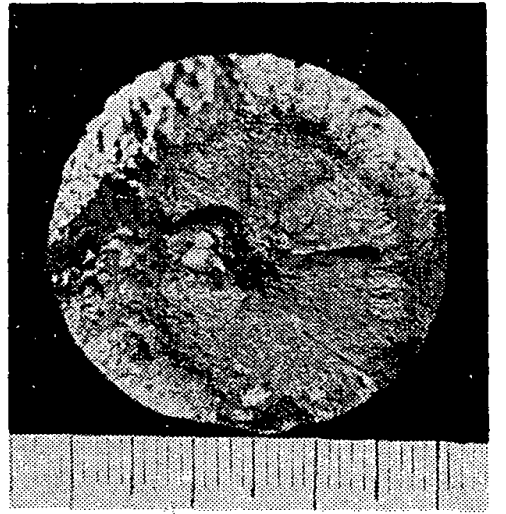

小ひけ

図24ひけを有する片振り引張り疲れ試験片の破断状沉 
ものである。ひけ欠陌は試験片のほほ中心部にあり， その久樎より全試験片ともき裂が発生している。

ひけ久陷の形状は外周の出入はあるが円形に近くな っていて，疲れき裂の発生はひけの最も大きい位置に 生している.

6.4 疲れ強さ表 5 は各試験片の $2 \times 10^{6}$ 回の応 力繰返し数における片振り弓張疲れ強さを示す。この 無欠陥材の弓張强さは $51.6 \mathrm{~kg} / \mathrm{mm}^{2}$ で, 疲れ強さは $26 \mathrm{~kg} / \mathrm{mm}^{2}$ である. 疲れ強さの弓張強さに対する比は 0.5 である.これに対し，小ブロホールのある場合で は疲れ強さが $15 \%$ ，中ブロホール $27 \%$ ，大ブロホー ル $54 \%$, 小ひけ $8 \%$, 中ひけ $23 \%$, 大ひけ $31 \%$ 低 下することがわかる。

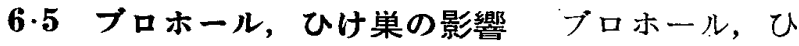
け巣の影響，特にひけ巣の影響を定量的に表わすた め，つぎのような欠陷率を考え，この值と疲れ強さと の関係を求めることにした。

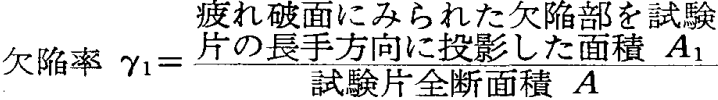

$$
\begin{aligned}
& \text { 放射線により互いに直角な } 2 \text { 方 } \\
& \text { 向から試験片を撮影し，その } \\
& \text { 欠陷率 } \gamma_{2}=\frac{\text { 写真方ら求めた年俻部面積 } A_{2}}{\text { 試験片全断面積 } A}
\end{aligned}
$$

図 25 は 線写真の代表例でおの掞のブロホールの ある場合、ひ汁のある場合の写蒖である。

$\gamma_{1}$ と $\gamma_{2}$ は, 大ブロホールの場合を除いては, 比較 的近い值を示した。しかし大ブロホールの場合は，試 験片の横断面方向に長さを有するブロホールがあった ため， $\gamma_{2}$ が著しく大きな值となった。

図 26 は, $\gamma_{1}, \gamma_{2}$ と $\sigma_{w 1}$ との関係を求めたものであ る.これによれば疲れ強さはブロホールの場合は欠陮 率に応じて低下する，ひけ久樎の場合は久陷率が小さ

\begin{tabular}{|c|c|c|c|c|c|c|c|}
\hline \multicolumn{8}{|c|}{$\left(N=2 \times 10^{8}\right)$} \\
\hline \multirow{2}{*}{\multicolumn{2}{|c|}{ 試験片種類 }} & \multirow{2}{*}{\multicolumn{2}{|c|}{ 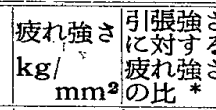 }} & \multirow{2}{*}{$\begin{array}{l}\text { 欠陌任d } \\
\text { 切欠 } \\
\text { 係数 }\end{array}$} & \multirow{2}{*}{ 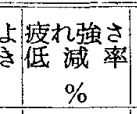 } & \multirow{3}{*}{\begin{tabular}{|c|} 
欠陷率十 \\
$\gamma_{\mathbf{1}}$ \\
0
\end{tabular}} & \multirow{3}{*}{$\begin{array}{c}\text { 欠陌率 } \\
\gamma_{2} \\
0\end{array}$} \\
\hline & & & & & & & \\
\hline & 欠 陌 & 26.0 & 0.50 & 1.00 & 0 & & \\
\hline 小 & ロホール & 22.0 & 0.43 & 1.18 & 15 & 0.2 & 0.2 \\
\hline 中 & ロホール & 19.0 & 0.37 & 1.37 & 27 & 0.9 & 0.5 \\
\hline & ロホール & 12.0 & 0.23 & 2.17 & 54 & 14.8 & 55.0 \\
\hline 小 & ひけ & 24.0 & 0.47 & 1.08 & 8 & 3.3 & 1.2 \\
\hline 中 & ひけ & 20.0 & 0.39 & 1.30 & 23 & 4.5 & 4.8 \\
\hline 大 & $a b$ & 18.0 & 0.35 & 1.44 & 31 & 6.6 & 7.7 \\
\hline
\end{tabular}
いときは強さ低下はほとんどなく，ある程度以上にな

裴 5 片振り引張試験片の疲れ強さ
れば強さの低下がみられる。

ひけ久陷は試験片の軸心部にあり，荷重方向に長さ を有する円柱状の欠陷であるため応力集中が割合に小 さく疲れ強さの低下む少ない。しかし欠陷率が大きく なると有効断面積の減少により疲れ強さが低下するも のと考えられる。

\section{7. 弓張圧縮疲れ試験}

$7 \cdot 1$ 試験方法 無欠陷および小ブロホールの2 種 の試験片について応力比をかえて実験を行なった．無 欠陷試験片は試験機の容量上直径 $20 \mathrm{~mm}$ のもの用 い, 小ブロホールのものでは $35 \mathrm{~mm}$ のものを用い た。試験機はローゼンハウゼン万能疲れ試験機（容量

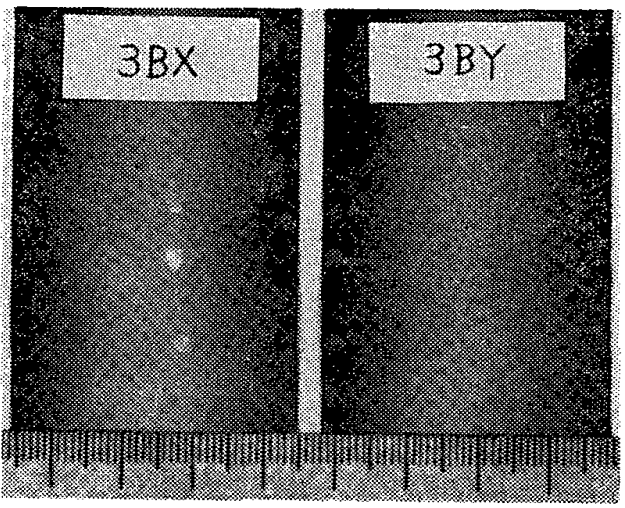

(a) ブロホール

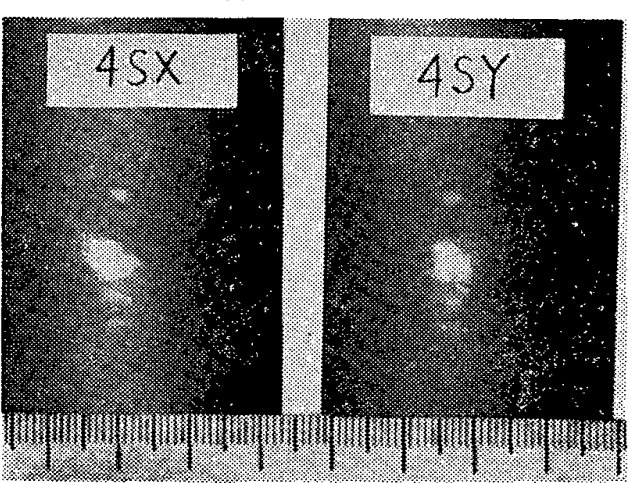

(b) ひけ

図 25 ブロホールとひけのX線写賣の一例

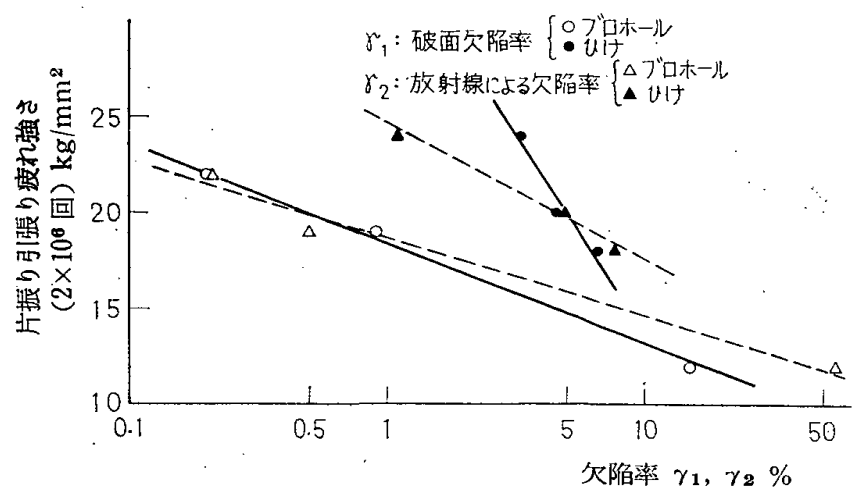

図 26 ・ブロホール年よびひけ灭陷武験片の久陷率 と疲れ強さの関係 
表 6 引張圧縮試験片の疲れ強さ

\begin{tabular}{|c|c|c|c|c|c|c|}
\hline & & & & & \multicolumn{2}{|c|}{$\left(N=2 \times 10^{6}\right)$} \\
\hline $\begin{array}{l}\text { 載験片の } \\
\text { 類 }^{2}\end{array}$ & $\begin{array}{c}\text { 疲れ強さ } \\
\mathbf{k g} / \\
\mathrm{mm} \mathrm{m}^{2}\end{array}$ & 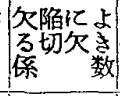 & 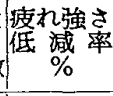 & 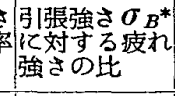 & 欠陥率 & 注 \\
\hline 無 欠 陌 & 17 & - & - & 0.33 & 0 & $\begin{array}{l}20 \mathrm{~mm} \\
\text { 試験片 }\end{array}$ \\
\hline 小，中 & 14 & 1.21 & 18 & 0.27 & 1.0 & $\begin{array}{l}35 \mathrm{~mm} \\
\text { 詿験片 }\end{array}$ \\
\hline
\end{tabular}

$* \sigma_{B}=51.6 \mathrm{~kg} / \mathrm{mm}^{2}$

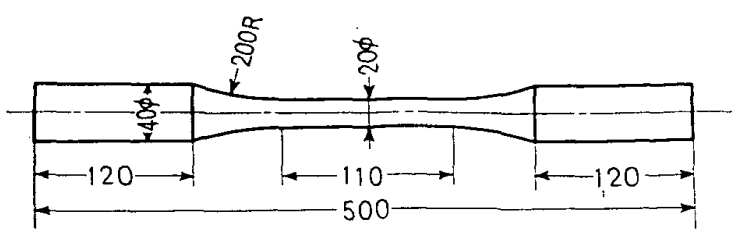

（a）無欠䧂試験片

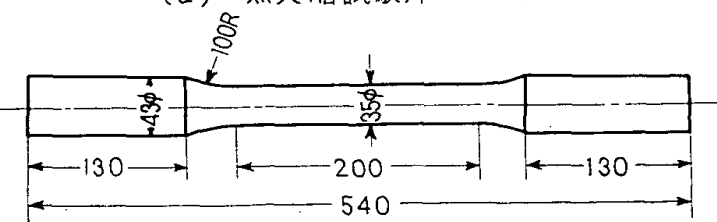

(b) 久陷武豎片

図 27 引張圧縮疲れ試験片

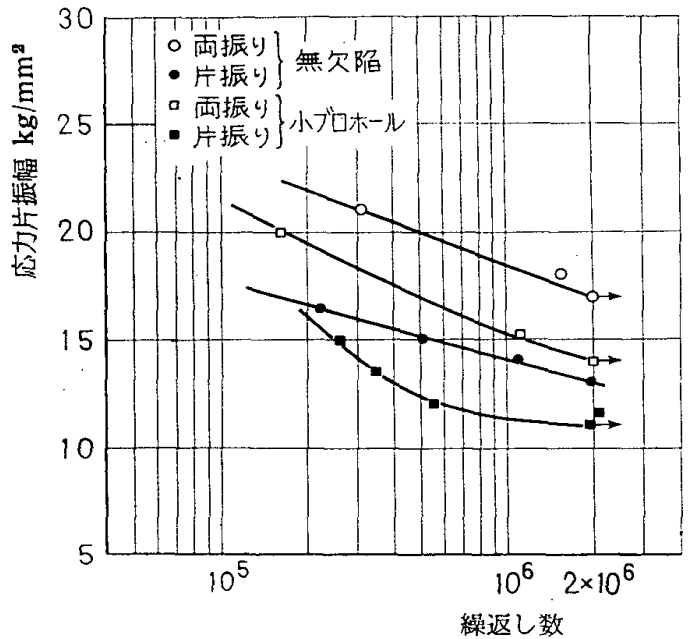

図 28 引張圧縮疲れ試験片の $S-N$ 曲線
$100 / 60 \mathrm{t}, 500 \sim 600 \mathrm{c} / \mathrm{min}$ ）を使用した。 引張圧縮試験 では断面内の庍力こう配がないので $20 \mathrm{~mm}$ と $35 \mathrm{~mm}$ では差はないとして取扱った。困 $27 に$ に試験片を示す。

$7 \cdot 2 S-N$ 曲線四 28 は実験結果を $S-N$ 曲線で 示したものである.なお前述の片振れの場合を片振幅 応力に直して傡記した。両者の $S-N$ 曲線の傾斜はほ 注等しい.

$7 \cdot 3$ 破断状況眼 29 は引張圧縮試験片の破断面 を示す。無欠郜試験片では片振れの場合との差はみら れない，小ブロホールの場合は表面からき裂が生ぜ ず, 内部のひ状の久陷からき裂が発生し，片振れの 場合と異なっている。これは庥力比の差がいくぶん影 響しているかも知れないが，試験片の欠陷の分布や形 状の相違による影響が大きいと考えられる。

$7 \cdot 4$ 疲れ強さ $2 \times 10^{6}$ 回の応力繰返しにおける 強さは表 6 に示すように直暒 $20 \mathrm{~mm}$ の無欠陷試験片 は $17 \mathrm{~kg} / \mathrm{mm}^{2}$, 直径 $35 \mathrm{~mm}$ の小ブロホール欠陥試験 片は $14 \mathrm{~kg} / \mathrm{mm}^{2}$ となった. 引張強さ $51.6 \mathrm{~kg} / \mathrm{mm}^{2}$ に対する比をみると無久陷材 0.33 ，小ブロホール材 0.27 となる。

7.5 引張圧縮疲孔限度線図 6 および 7 章の実 験により SC 46 の丸棒仕上げ試験片の弓張王縮およ

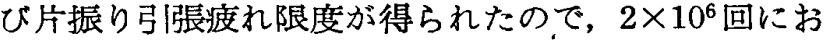
ける痩れ限度線図を求めた。図30はこの線図であ る。

無欠陥の場合も小ブロホールの場合も，罒の点線で 示すように両振れと片振れを結ぶ直線と横軸との交点 はほほ一致し前者では $60 \mathrm{~kg} / \mathrm{mm}^{2}$, 後者では $58 \mathrm{~kg}$ / $\mathrm{mm}^{2}$ となった。

これはブロホールによる強さ低下係数(切欠き係数) は応力振幅にのみきき，平均応力にははとんぞきかな いことを意味している，したがった平均庥力が高く， 片振れ凩力の小さい領域で使用する際には，ブロホー

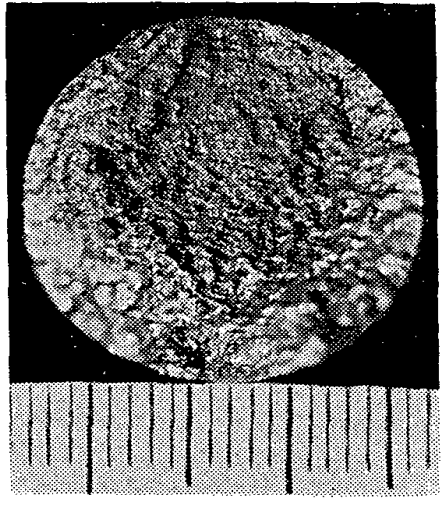

(a) 欠陷

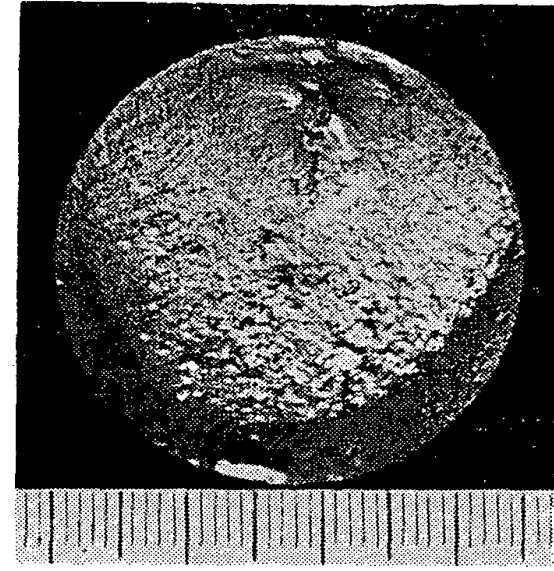

(b) 小ブロホール

ルによる強さ低下はほとんど考えなくてよい ことになる。

平均応力を材料の引張强さ $51.6 \mathrm{~kg} / \mathrm{mm}^{2}$ にとりこの点と求められた片振り疲れ強さ の点を結べば罒の実線のようになる。これは 平均応力が大きく，振幅応力の小さい範国で 疲れ強さが下方にだれる傾问がある点を考慮 してひいたものである.

小ブロホールの結果から中および大ブロホ 一ルの疲れ限度線図を，引張强さにはこれら の久陷はほとんど影響しないことを考え，類 推して描くと眓中の各線のようになる.

図 29 引張王縮疲九試験片の破断面 


\section{8. 結論}

普通鋳銅品（SC 46）の疲独さについて研究しつ ぎのような結果を得た（表 7 参照）。

(1) 回転曲げ渡れ強さ

(1) 健全な鋳鋼品の疲れ限度は試験片の大きさによ って異なるが，10〜100 mm の試験片の範囲では，引! 張強さの $0.46 〜 0.36$ 倍である. 試験片の小さいとき のほうが瘦れ限度は大きい。また同じ弓張強さの銀鋼 品に比らべれば，その約 $80 \%$ 程度である。

(2) 微細なポロシティを有する鋳鋼品の痩れ強さは 健全なものと㚆わらない.しかしこのような場合の破 面は疲れ破面につづいてひどいあばた状の破面を呈す る.

(3)ブロホールを有する錆鋼品の疲れ強さは低下す る.その低下度合は穴径の対数值に比例する.

(4) 試験片の大きさのいかんにかかわらず久陷材の 疲れ限度 $\sigma_{w 0}$ （穴の大きさを無視して求めた疲れ限 度) は, $d / D=0 \sim 0.2$ 範国では穴の大きさのみによ ってほほ決まる。

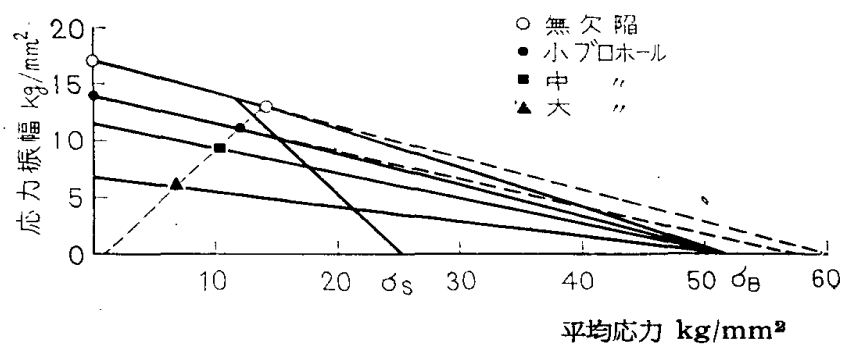

図 30 普通鋳鎆品の引張圧縮疲九限度線図

表 7 疲れ強さと引張強さとの比

\begin{tabular}{|c|c|c|c|c|c|c|c|c|}
\hline & \multirow{2}{*}{ 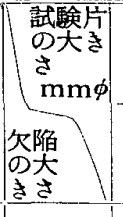 } & \multicolumn{4}{|c|}{$\begin{array}{c}\text { 回転曲げ技れ限度 } \\
\left(N=1 \times 10^{7}\right)\end{array}$} & \multirow{2}{*}{ 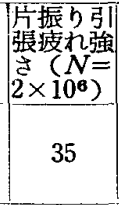 } & \multicolumn{2}{|c|}{ 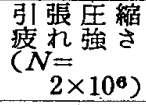 } \\
\hline & & 100 & 64 & 50 & 10 & & 20 & 35 \\
\hline 健 全 & $\mid \begin{array}{c}0 \sim 0.2 \\
\mathrm{~mm} \phi\end{array}$ & $\begin{array}{l}0.36 \\
? \\
0.38\end{array}$ & & $\begin{array}{l}0.38 \\
1 \\
0.41 \\
\end{array}$ & $\begin{array}{l}0.44 \\
i \\
0.46\end{array}$ & 0.50 & 0.33 & \\
\hline 小ブロホ & $\left|\begin{array}{r}0.4 \sim 1.5 \\
\mathrm{~mm} \phi\end{array}\right|$ & 0.22 & & 0.31 & & 0.43 & & 0.27 \\
\hline 中ブロホ & $\begin{array}{c}1.5 \sim 3 \\
\mathrm{~mm} \phi\end{array}$ & & & 0.24 & & 0.37 & & \\
\hline 太ブロホ & $\begin{array}{l}3 \sim 8 \\
\mathrm{~mm} \phi\end{array}$ & 0.17 & - & 0.21 & & 0.23 & & \\
\hline 小ひけ単 & \begin{tabular}{|c|} 
全面積の \\
$3.3 \%$
\end{tabular} & & & & & 0.47 & & \\
\hline 中ひけ巣 & $\left|\begin{array}{c}\text { 全面皘の } \\
6.5 \%\end{array}\right|$ & & & & & 0.39 & & \\
\hline 大ひけ柴 & $\left|\begin{array}{|c|}\text { 全面積の } \\
8.0 \%\end{array}\right|$ & & & & & 0.35 & & \\
\hline ひけ割れ & $\begin{array}{r}1.0 \sim 4.5 \\
\mathrm{~mm}\end{array}$ & & 0.19 & & & & & \\
\hline
\end{tabular}

(5) ひけ巣が試験片の軸心部にあるものでは，直径 の 1/10 以下のものはその影響は全くない.

(6)ひ割れが表面にあるものは疲れ限度は大きく 低下する。ひけ割れが $1.0 \sim 4.5 \mathrm{~mm}$ のもので度れ限 度は $9 \mathrm{~kg} / \mathrm{mm}^{2}$ であり, $3.0 \sim 4.0 \mathrm{~mm}$ のブロホール を持つものの疲れ限度 $\left(10 \mathrm{~kg} / \mathrm{mm}^{2}\right)$ よりも低い.

(2) 片振り弓張疲れ強さ

(1) 無欠陷材の疲れ強さ $\left(N=2 \times 10^{6}\right)$ は引張強さ の 0.50 である.

(2)ブロホールがあれば疲れ強さは低下する.小ブ ロホールでは約 15\%，中ブロホールでは $27 \%$, 大ブ ロホールでは $54 \%$ 低下する.

(3)ひけ巣によって疲れ強さは低下する．小ひけ单 では約 8\%，中ひけ巣では $23 \%$,大ひけ巣では $31 \%$ 低下する。

（3）弓張圧縮疲れ強さ

(1) 無欠俻材の疲れ強さ $\left(N=2 \times 10^{6}\right)$ は引張強さ の約 0.33 である.

(2) 小ブロホールがある場合の疲れ強さは引張強さ の約 0.27 である.

(4) 弓張圧杀宿疲れ限度線図

図 20 に示すように健全材・准材の弓張圧縮疲れ 限度線図を求め得た。

\section{9.あとがき}

本研究は日本鋳鋼会において神戸製鋼，川崎製鉄， 小松製作，住友金属，日本製鋼，日本鉡鍼，日本鋳造， 新潟鉄工，日立製作，三菱製鋼などならびに東京都立 工業奖励館，日本海事協会，日本船舶振興会などの協 力を得て行なったものである.この他鋳鋼品の黑皮の 影響，溶接の影響ならびに熱痩れ強さについても実験 を行なったが，これらは紙面の都合上別の機会にゆず り，本論文では表面仕上げを行なった丸棒の場合のみ を取りあげて報告した、データ不足の部分もあるが初 期の目的をだいたい達し得たものと考えている.ここ に関係された諸氏に厚ぐ感謝の意を申し上げる次第で ある。

\section{文献}

(1) 松浦, 機械学会誌, 63-503 (昭 35-12)，1622.

(2) R.E. Peterson, Stress Concentration Design Factors, (1959), John Wiley and Sons.

（3）疲九強さの設計資料 [I]，(昭 36)，機械学会.

(4) R.E. Peterson \& A.M. Wahl, Trans. ASME, 58 (1936), A-15, A-146.

(5) F. Körber \& M. Hempel, KWI Mitt., 21 (1939), 1. 